Illinois State University

ISU ReD: Research and eData

Theses and Dissertations

3-19-2021

\title{
A Comparison of Financial and Residential Quality of Life by Housing Provision in Taiwan
}

Chia-Hang Hsu

Illinois State University, chsu123@ilstu.edu

Follow this and additional works at: https://ir.library.illinoisstate.edu/etd

\section{Recommended Citation}

Hsu, Chia-Hang, "A Comparison of Financial and Residential Quality of Life by Housing Provision in Taiwan" (2021). Theses and Dissertations. 1442.

https://ir.library.illinoisstate.edu/etd/1442

This Thesis is brought to you for free and open access by ISU ReD: Research and eData. It has been accepted for inclusion in Theses and Dissertations by an authorized administrator of ISU ReD: Research and eData. For more information, please contact ISUReD@ilstu.edu. 


\section{A COMPARISON OF FINANCIAL AND RESIDENTIAL QUALITY OF LIFE BY HOUSING PROVISION IN TAIWAN}

\section{CHIA-HANG HSU}

\section{Pages}

This is a study about the relationship in Taiwan between housing provision (homeowner, family-owned, rented, allotted, or other) and quality of life (both financial \& residential quality of life), with separate analyses for the average Taiwanese household and for households in the bottom decile of the income distribution. This thesis finds that Taiwanese renters, both in the nationally representative sample and in the bottom decile of household income, are more likely to have a lower financial and residential quality of life compared to those living as homeowners, even after controlling for income, family type, and age of household head. Also, there is an interesting finding that homeowners with mortgages unexpectedly have a higher quality of life than homeowners without mortgages. This shows that there are benefits of improved quality of life from homeownership even when homeowners are paying off their mortgage. Therefore, studying the influences of housing provision is a possible contribution to improving poor families' well-being. Finally, in order to improve all Taiwanese people's well-being, this study suggests that the Taiwanese government should introduce policies to reduce the housing prices and create a healthier housing market for both rental and for-sale houses.

KEYWORDS: Homeownership; housing provision; quality of life; poverty; Taiwan 
A COMPARISON OF FINANCIAL AND RESIDENTIAL QUALITY OF LIFE BY HOUSING PROVISION IN TAIWAN

CHIA-HANG HSU

A Thesis Submitted in Partial

Fulfillment of the Requirements for the Degree of

MASTER OF SCIENCE

Department of Sociology and Anthropology

ILLINOIS STATE UNIVERSITY 
(C) 2021 Chia-Hang Hsu 
A COMPARISON OF FINANCIAL AND RESIDENTIAL QUALITY OF LIFE BY HOUSING PROVISION IN TAIWAN

CHIA-HANG HSU

COMMITTEE MEMBERS:

Aaron Pitluck, Co-Chair

Marion Willetts, Co-Chair

Maria Schmeeckle

T Y Wang 


\section{ACKNOWLEDGMENTS}

On July 31 st, 2019, I set foot on American soil again. This is a brand-new page of my life and my career. It is an interesting but not easy journey for me. The first thing I faced was waiting for the delayed bus for more than 40 minutes with two large suitcases and an anxious mood. However, I am the luckiest person and there are a lot of people who helped me to deal with all problems I got. First of all, I really want to thank Illinois State University and the Department of Sociology for giving me the chance and financial support to pursue a master's degree in the United States. Without the teaching assistantship and tuition waiver, I could never be here to study the program I am eager to. Also, I appreciate the supports and all courses taught by the professors of the sociology department. Without these courses and professors' help, I could never finish this thesis. I want to express the depth of my gratitude to all the professors I have met in this school, especially to my committee members, Dr. Pitluck, Dr. Willetts, Dr. Schmeeckle, and Dr. Wang. Without anyone of you, I couldn't finish this study. All I can say is - thank you very much! Moreover, I want to thank my parents, without your support, mentally and financially, this is impossible for me to be in another country living by myself. Finally, I want to thank my partner, Ting-Hui Lin, who provides me so many ideas and insightful suggestions for my thesis; and my cat, Gogo, you have given me huge moral support during the tough time of my work. 
ACKNOWLEDGMENTS

CONTENTS

TABLES

iv

CHAPTER I: INTRODUCTION 1

CHAPTER II: LITERATURE REVIEW

Housing Policies in Taiwan $\quad 4$

Housing Policy Models $\quad 4$

Housing Policies and Housing Commodification 5

$\begin{array}{ll}\text { Rent } & 9\end{array}$

$\begin{array}{ll}\text { Influences of Homeownership in Taiwan } & 10\end{array}$

$\begin{array}{ll}\text { Housing Provision } & 12\end{array}$

$\begin{array}{ll}\text { Objective Quality of Life } & 15\end{array}$

Relevant Research Indicator of Quality of Life $\quad 16$

Relationship between Quality of Life and Age, Family Structure, and Income 17

$\begin{array}{ll}\text { Housing Provision and Quality of Life } & 18\end{array}$

Official Definition of Low-Income and Middle-Low-Income Family in Taiwan $\quad 20$

$\begin{array}{ll}\text { The Poverty Line in Taiwan } & 22\end{array}$

CHAPTER III: METHODOLOGY 25

$\begin{array}{ll}\text { Data } & 25\end{array}$

Population/sample/units of the data $\quad 26$

Survey method of the data $\quad 26$

$\begin{array}{ll}\text { Variables } & 27\end{array}$

$\begin{array}{ll}\text { Dependent variable } & 27\end{array}$ 
$\begin{array}{ll}\text { Independent variable } & 28\end{array}$

$\begin{array}{ll}\text { Control variables } & 29\end{array}$

$\begin{array}{ll}\text { Analytical Strategy } & 33\end{array}$

CHAPTER IV: RESULTS 34

CHAPTER V: DISCUSSION AND CONCLUSION 48

$\begin{array}{lr}\text { REFERENCES } & 57\end{array}$

APPENDIX A: TABLES FOR ALL SAMPLES 66

APPENDIX B: TABLES FOR THE BOTTOM DECILE OF HOUSEHOLD INCOME 96 


\section{TABLES}

Table

Page

1. Data of Area Per Capita 27

2. Data of Household Equipment 28

3. Data of Household Expenditures 28

4. Distribution of Housing Provision 29

5. Data of Age of Household Head 30

6. Data of Number of Persons 30

7. Distribution of Type of Family 32

8. Household Income 33

9. OLS Regression Models of Index of Room Area Per Capita, Household Equipment and, Household Expenditures on Housing Provision Dummies and Controls

10. OLS Regression Models of Index of Room Area Per Capita, Household Equipment and, Household Expenditures on Housing Provision Dummies and Controls for the Bottom Decile of Household Income 


\section{CHAPTER I: INTRODUCTION}

In this study, the crucial research question is how housing provisions in Taiwan—such as whether a household owns their home, rents, or has an alternative arrangement — affects people's quality of life in different income groups. This study uses statistical analysis to explore the causal relationships between such housing provisions and financial and residential quality of life, such as their family expenditure, the quality of their housing, and their living space per person.

Current studies of housing provisions in Taiwan have examined gender inequalities and generational inequalities. However, there is not much research on poor people or low-income families' housing provisions. Since poor people are the most vulnerable group, are the most likely to rent, and are affected most by rental prices, we need more research to reveal the relationship between housing provisions and poor people's quality of life.

There appear to be problems in the existing literature on how housing provisions affect the quality of life of households in Taiwan. The first is that the literature has poorly understood the quality of life of the poor because of the Taiwanese government's restrictive definition of "low-income" in Taiwan. Taiwan has the lowest official poverty rate in the world due to the restrictive definition of "low-income family" in Taiwan. Because of the lowest poverty rate in Taiwan and many criticisms by Taiwanese scholars that the rule of household property cap is too strict, families categorized as “low-income families" doesn’t accurately represent the poverty situation in Taiwan. Thus, it is common that social researchers use relative poverty such as $20 \%$ or $5 \%$ rather than the government's definition of low-income families (Chen, 2001; Zhu, 1987). This study adopts the definition of "lowincome" households as the poorest $10 \%$ of households because a government report (Directorate General of Budget, Accounting and Statistics, Executive Yuan, 2011) based on OECD's method in 2011 found that the poverty rate was 7.7\% in Taiwan. 
The second and related problem is that existing research has almost entirely overlooked the question of how renting affects the poor-perhaps because Taiwan's rental market is almost non-existent with the exception of renting to low-income households. In 2018, the homeownership rate among low-income families in Taiwan was 37.55\% (Ministry of Health and Welfare, R.O.C.(Taiwan), 2019) compared to the national homeownership rate of $84.52 \%$ (Directorate General of Budget, Accounting and Statistics, 2019). This is a complicated situation in Taiwan. On one hand, this difference might be caused by the official wealth restriction of "low-income family" that people, who are qualified for "low-income family" identification, can own only a very limited value of wealth such as real estate or stock in Taiwan. On the other hand, this phenomenon still shows that the poorest families in Taiwan include a huge proportion of people who are renters. By any means, low-income families are more likely to be affected by rent since they are less likely to own their own houses.

Rent takes a significant portion of people's income. Official reports show that even though the highest family expenditure across all people is still food, this proportion is decreasing. On the other hand, housing expenses as the second major family expenditure are slightly increasing in Taiwan (Report on the Survey of Family Income and Expenditure, 2018). Evidence and literature suggest that how poor people access housing can be an important factor influencing their life quality.

This thesis addresses this research gap: how does housing provision affect Taiwanese households' quality of life, particularly the poorest $10 \%$ of households? This study addresses this question using OLS regression analysis of data collected in the "Report the Survey of Family Income and Expenditure, 2018” collected by the Directorate-General of Budget, Accounting and Statistics Executive Yuan, Republic of China (Taiwan). 
This thesis finds that Taiwanese renters, both in the nationally representative sample and in the bottom decile of household income, are more likely to have a lower financial and residential quality of life compared to those living as homeowners, even after controlling for income, family type, and age of household head. Therefore, studying the influences of housing provision is a possible contribution to improving poor families' well-being. In Taiwan, poor people's housing provisions may not be based on their free will but forced by their economic situation or environment. In contrast to those who choose to buy a house, housing provision may affect poor families' life quality because they are forced to rent. Poor people are excluded from this discussion, and in my opinion, their housing choices warrant more critical attention. 


\section{CHAPTER II: LITERATURE REVIEW}

\section{Housing Policies in Taiwan}

Housing policies significantly affect a nation's housing structure, rent, and the market. In order to answer the questions about poverty, housing, and quality of life, it is necessary to review the housing policies in Taiwan.

\section{Housing Policy Models}

According to John Doling (1999), he referred to David Donnison's (1967) classification of housing policy regimes that there are three kinds of housing policy systems. To identify and classify housing policy models, Donnison divides housing into three stages: (1) development, (2) construction, and (3) consumption. The way a nation deals with these three stages determines the housing policy regime they represent. According to Donnison, the different market-state mixes constitute the basis of a typology of housing policy regimes. First, liberal regime, in a purely capitalist country, private sector interests dominate at all stages. State only intervenes if family cannot find a solution in the market. Houses are built by private firms. Houses are considered private goods. The price and quality are affected by consumers' ability and willingness to pay. Country does not provide many houses. For example, the US, Canada, and Australia belong to this category. Second, communist regime, in a purely communist country, all three stages would be controlled by state interests. Lands are held by the government. Housing is seen as a basic right to citizens. Thus, the government uses the overall plan, state-owned construction companies, and state capital to develop. Rent would be near zero. Third, corporatist regime, a middle way. For example, in Sweden, the Netherlands, and Denmark, in these countries, markets construct housing, but the nation controls the number, the type, and the location of houses in order to be subservient to societal interests. They have a large number of rental houses. They secure an attractive rental price for families in order to depress the demand for homeownership. 
Donnison used the classification to investigate old industrialized countries (OIC).

Doling then uses the same idea to compare newly industrialized countries (NIC). Among the Asian tigers, there are two different directions. In Hong Kong and Singapore, perhaps because of the constraints imposed by the high population density, the governments have earlier and stronger interventions. However, in the consumption stage, this seems different from social housing in the OIC. In this model, allocation more closely reflects principles of ability to pay than those of need. The case in South Korea and Taiwan is different. These two nations were dominated by the government in the early era. Since the influence of the US has been getting stronger, housing has been less directed by the state but more by the liberal market. In other words, Taiwan and South Korea were following the communist way since the states had dominated housing development, construction, and consumption in the past. Yet, as a result of the powerful influence of the United States on them, these two nations are more fitting to the liberal regime model now. As an essential process towards a liberal regime, the relationship and interaction between housing commodification and the government are important.

\section{Housing Policies and Housing Commodification}

In recent history, housing has been changed as a financial commodity. Housing commodification means that housing is not a right but a profitable good. Since 1960, housing has been the largest expenditure in the average American household budget. Housing costs were rising faster than incomes during much of this era. Housing becomes a consumer good like a car, a couch, etc. The reliance on housing as a wealth-producing commodity may be related to the government policies (Pattillo, 2013).

Housing policy in Taiwan has several eras. Between 1949 to 1975, because the government of the Republic of China retreated from mainland China to Taiwan, approximately 2 million refugees and soldiers migrated to Taiwan. During this period, the 
main goal of the government was to meet the high demand for housing. There were three main principles of the land reform related to urban area: (1) regulating land value, (2) taxing and compulsorily purchasing land according to its value, and (3) giving the unearned value of land to the people (Grange, 2006). In the KMT dictatorship era, the government did not just control the value of lands but also redistributed land to people by expropriation. Also, the government led the development of all infrastructure such as public transportation, power station, and water supply. The government provided small, low-quality, and cheap houses and low interest rate loans to people. The government focused on impoverished people and civil servants (soldiers, government employees, and teachers). However, because of the overwhelming threat of invasion, resources were concentrated on national defense rather than housing. Before 1976, the government basically ignored the large demand for refugee housing. Instead, the government allowed the people to solve the housing problem by themselves. Thus, the housing quality was terrible in that era. There was a survey showed that the average living space was about $7.1 \mathrm{~m} 2$ (76.4 square feet), $15 \%$ of households had no kitchen, $52 \%$ had no bathroom, and 30\% had neither a bathroom nor running water (Wen, 1988).

Between 1975 to 1994, along with the publishing of the Public Housing Act, the housing policy started toward legalization and institutionalization. The Public Housing Act allows the government to collect lands to build cheap public houses for poor people. The government planned to build 200,000 public houses between 1990 to 1996 . However, the program failed because the public houses were in terrible locations, oversupplied, and too expensive for lower-income people. The government, thus, stopped building public housing in 1999 . Furthermore, before 1999, the government also changed housing policy. The Taiwanese government introduced the private sector for public housing construction and provided subsidies for housing purchases. 
Due to rapid population growth, urban development has changed dramatically in Taiwan. In 2003, 69\% of the population in Taiwan was urbanized. Along with urbanization and loosening regulations by the government in Taiwan, houses began to commodify. According to Doling's (1999) classification, housing has been liberalized and this was accompanied by the commodification of houses (Grange, 2006). However, according to Grange's study, commodification is incomplete. Taiwan is a paradoxical case. In spite of the government's motivation to curb speculation and ensure rational urban development to fulfill the needs of community and economy, this quite draconian legislation has had little impact to slow down the commodification process. The land tax only made the processes inconvenient.

Public development also can be a factor to increase housing commodification. For example, in order to reserve lands for public services, the government compulsorily acquired and reserved lands as Lands Reserved for Public Facilities (LRPF). In the beginning, LRPF sites were acquired with no compensation to their owners. Later, the government planned to set aside NT\$700 billion (US\$28 billion) to buy LRPF sites to respond to the protest of landowners. In 1996, the Constitution Court asserted that some cases of land appropriation for road construction without adequate compensation were unconstitutional and restitution should be made. The potential cost is about US\$90 billion. This eroded the ability of local governments to provide urban services (Chou, 1998). Although LRPF's original meaning was to reserve areas for public services, the practice of LRPF has not achieved the goal of benefiting the interests of communities. Instead, it encouraged land speculation. In addition, the government refused to intervene in the actual development of these lands. Via politicalbusiness collusion, the government only played the role to allocate land. Almost all private developers have political party backgrounds.

From 1994 to 2005, the private sector started to participate actively in the construction of low-income houses for sale. However, the plan of introducing private sector low-income 
housing was a failure. It terminated after building 18 construction projects including 1,771 units because there were a large proportion of houses that did not sell. On the other hand, the interest subsidy introduced in this time period continues to be a major part of Taiwanese housing policies. There were 248,561 loans that had been approved by 2002 . This shows that there was a high demand for housing in the 1990s which can be traced to the rapid urban development accompanied by housing commodification in Taiwan.

From 2005 to the present, the Overall Housing Policies set to improve the housing market and improve housing quality and fair efficiency of housing subsidies as the housing policy goals (Chen, 2008). In addition, after 2011, the government introduced Housing Act, construction of public houses has started again, especially in urban areas in Taiwan. For example, Tainan city introduced a public housing project for young people in 2021 (Li); on average there are about 2,400 units of public houses built annually in Taipei since 2014 (Department of Urban Development, Taipei City Government). However, the social housing rate is only $0.156 \%$ until 2018 in Taiwan, still lower than many other countries such as the US (5\%), Netherlands (32\%), the UK (18\%), Japan (6.1\%), Singapore (4.5\%), Hong Kong (29\%), and South Korea (5.1\%) (Wang al et, 2020).

The case study of Taiwan shows that the efforts of deterring commodification of housing in Taiwan is unlike Hong Kong and South Korea and more similar to Singapore. On the one hand, the state has withdrawn from the housing market to liberalize it (Ronald, 2007). On the other hand, the Taiwanese government legislates laws in order to slow down housing commodification. Ironically, while the regulatory regime and policy rhetoric have treated land as an incompletely commodified good, land and housing are almost totally commodified in Taiwan, and the country has one of the most speculative land and housing markets in Asia. This speculation has driven up housing prices. 


\section{Rent}

Lan and Lee's case study of Taipei City (2020) once again confirmed the rising commodification of housing in Taiwan. The Urban Renewal Act encourages construction companies to build houses and apartments with a high proportion of public area. Despite the good intentions of the Urban Renewal Act to improve urban housing quality, it has created extra costs on companies, thereby increasing housing prices and rent. Moreover, Lan and Lee suggest that this has also caused a regional polarization. The urban-rural gap between housing prices and rents has been severely widened due to government policies. As result, housing policy has failed to relieve commodification, instead, the housing price keeps increasing in Taiwan. Because the non-occupied housing holding tax is only $1.5 \%$ to $3.6 \%$ in Taiwan and the base tax is decoupled with market value, the tax base is referred to as government announcement value. Thus, a US\$617,100 apartment in Taipei is only taxed US\$200 per year. Due to the low holding cost, in 1978 , the homeownership rate was $69.57 \%$ (The Survey of Family Income and Expenditure, 2018) and rich people usually own many houses; $10 \%$ of households owned $40 \%$ of dwellings in Taipei (Wen, 1988). Chang (1995) found that $13 \%$ of properties in Taiwan were vacant in both 1980 and 1990, which is far higher than natural vacancy rates. It is an extreme phenomenon especially in Taipei, housing stock have primarily an exchange value rather than a use value. The rental market is also affected by this phenomenon so that landlords have little pressure because the holding cost is low.

In recent years, because of the uncommonly high homeownership rate $(85 \%)$, the proportion of renters is barely close to $10 \%$ in Taiwan. Still, the home ownership market and rental market influence one another. The lower income families are more likely struggling from the increasing rental housing prices because they have no financial flexibility to choose between renting or owning a home. According to Peng (2004), therefore, it has become a trend that house rentals grow every year gradually. Peng studied the relationship between 
housing rent and price in Taiwan. He suggests that the housing and rental prices are positively correlated. When housing prices increase, the motivation for buying a house will decrease. So, there will be fewer people who are looking to buy houses. Instead, there will be more people in the rental housing market. Thus, owners with their unsold houses join the rental market. On the other hand, when rental prices rise, more people will seek to stop renting and to purchase a house. Thus, the number of renters will decrease. However, because of the low housing holding cost, housing prices never decrease in Taiwan, especially in urban areas. House owners would rather hold the vacant house and the selling price than reducing the price for sale. Since house owners have no cost pressure, they also do not cut down the rental price. Thus, this forms a vicious circle that especially affects people who do not have the ability to own houses. There are fewer people who "choose" to rent. Most of the renters are forced to rent because they do not have enough money or a stable income (Peng, 2004).

\section{Influences of Homeownership in Taiwan}

In general, housing constitutes a large part of households' property and expenditure throughout Taiwan. Housing provision obviously affect families' other forms of consumption, such as food or transportation. However, poor people have no choice but to rent a home. The official statistics show that the rate of homeownership was $84.52 \%$ in 2018 . Combined with the percentage of homes owned by spouses, parents, or children not living together $(4.7 \%)$, and homes allotted ${ }^{1}$, borrowed, or "others" $(2.75 \%)^{2}$, the number of nonrenting people is approximately $92 \%$. Only $8 \%$ of the population are tenants in Taiwan (Report on The Survey of Family Income and Expenditure, 2018). In contrast, among the poorest $4 \%$ of Taiwanese (so-called low-income families), the rate of homeownership is only $30.62 \% .47 .52 \%$ of low-income families are tenants, $18.12 \%$ are borrowed, $0.13 \%$ are

\footnotetext{
${ }^{1}$ Which means that the house is owned by government, school, firm, or group.

${ }^{2}$ Which means that the house is borrowed from other people or organization without any cost.
} 
allotted, and $0.48 \%$ are categorized as "others" (Report of the Low-income and Middle-lowincome Family Living Condition Survey 2018). These facts show that poor people are more likely to experience the stress of rent.

Hsueh and Chen (1998) investigate the comparison of household expenditures by housing provision in Taiwan. In this research, the authors compare the consumption patterns between house owners and tenants in Taiwan. They found that although both groups are spending the most on food, they are very different in other expenditures. First of all, house owners have a higher household expenditure compare to renters. The average difference is about US\$2700 per year. Second, people who own houses are spending a higher percentage of money on long-term products such as electrical appliances, health care, communication, and transportation. On the other hand, tenants spend more on food and clothes.

Hsueh and Chen also emphasize the influence of age; they found that middle-aged people, who have owned houses for a longer period of time, experience lower pressure of expenditure than renters. They are able to spend more money on other categories such as luxuries rather than the house. In contrast, younger house owners experience more pressure from houses because of the higher housing price. Also, younger renters have more flexibility in expenditure on food compared to homeowners of the same age. To sum up, homeowners tend to spend money on the household such as household equipment, tenants spend more on personal products such as clothes.

This study was using the same dataset as this thesis. The authors conduct ordinary-least squares regression to analyze the differences of each expenditure between homeowners and tenants by 6 age groups. This study shows an initial result that housing provision has significant influences on people's consuming behavior. The authors mentioned in the conclusion that "...homeowners have an obviously different consumption preference compared to renters." “...In general, homeowners have a higher stability of life so they are 
more likely to spend more income on expenditures which can improve the family's quality of life." To sum up, this is a study that used a similar method as this thesis. However, they did not conduct an analysis on poor families and they did not distinguish between homeowners who have a mortgage from those without this large debt. Both of these missing variables are likely to influence consuming behavior (as well as quality of life). These are a part of the important question this thesis is going to answer.

\section{Housing Provision}

Previous research has examined how family structure, gender, and age affect housing provisions. For example, Wu and Hsu (2004) compared the housing provision of single parents and found that single-parent households headed by widows have the highest probability of owning a home, while single-parent households following a divorce separation have the lowest probability of owning a home. Single fathers are more likely to own a house than single mothers, and low-income single mothers are the least likely to own a house. Li and Hsieh (2017) studied the different factors between males and females that affect the housing provision. For example, males have more wealth and income that bring them advantages to purchase a house. On the other hand, females' homeownership is highly affected by spouses, retirement age, and region. Chen and Chang (2000) analyzed the relation and interaction of housing provision, household composition, and household savings. Peng (2012) investigated the influences of costs of owning to arrangements. Hsueh, Lin, and Yen (2009) studied the housing provision and housing consumption among different male birth generations.

These studies all agree that due to increasing housing prices, how to reduce housing inequality is more and more important. Previous studies can be classified into three categories, the first being investigations of gender inequality. Males in Taiwan continue to dominate the workplace and control the economic power of households so that women have 
less economic independence than men (Wu \& Hsu, 2004; Li \& Hsieh, 2017). Consequently, the housing provision among females, particularly single mothers, are shaped by the agency of men. For example, Wu and Hsu's (2004) study shows that divorced women are less likely to own a house compare to widowed women.

Second, scholars have focused on the factors affecting housing provision. They are interested in how factors change people's choices. For example, Chen \& Chang (2000) analyze the relationship between saving and housing provision. They found that Taiwanese families who own houses without a mortgage have the highest average saving rate $(21.31 \%)$. Families that own houses with mortgages have the lowest average saving rate (16.14\%). Tenant families' average saving rate is $20.95 \%$. Interestingly, approximately half of single generated tenant families' saving is "compulsory savings" which is savings for future homeownership. Gender and region are also relevant. For example, arrangement among females is affected by spouses, retirement age, and region. There is an increasing chance that retired household heads are more likely to own houses. More specifically, the chance of female head is increased by $7.5 \%$, but the chance of male head is only increased by $3.88 \%$. Also, female and male household heads have regional difference of homeownership. For example, male and female heads both are the most likely to own a house in the southern region. However, female heads are least likely to own a house in the North. In contrast, men are less likely to be affected by these factors. Also, men have more advantages of wealth and income. In addition, the region in which one lives affects one's housing choices. Taipei is the biggest city in Taiwan. The average housing price in Taipei is 2.82 times the national average, but Taipei has the smallest average living area per person (Li \& Hsieh, 2017). This indicates a problem that it is difficult to be a house owner in Taipei, but the housing quality has not improved with the price. 
Finally, the difference between generations. Hsueh and Yen's (2009) study revealed that for people born after 1970, the possibility of owning houses decreased significantly due to the skyrocketing housing prices in the 1980s. Hsueh and Chen (1998) discovered that people of different ages act differently by making distinct housing provision. However, they also argue that the pattern is not very clear. They were not able to explain the influences of age.

Housing provisions have a serious impact on people's quality of life. Taiwan Labor Front (2018) analyzes 6 major cities' rental houses data on the "591 website" in order to demonstrate the housing dilemma of minimum wage workers. The family expense of housing in the lowest score in the quintile of income in 2016 is $32 \%$. Since the rent is raising, the financial stress has increased for those who earn minimum wages. Especially for single tenants, the housing market in Taiwan is not friendly to single-tenants or single parents with low incomes (especially single mothers). Landlords tend to create several rules for a single tenant. For example, only lease the apartment to females, do not lease to people with children, do not allow tenants to cook in the apartment, or prohibit pets in the apartment. Single mothers are facing a more difficult situation because they have lower income and lower family support than single fathers.

This study shows that lower rental price usually brings stricter rule and a poorer housing environment; both cause a worse living standard. For example, many landlords lease a top extra floor for tenants. These rooms are often leased to too many people and are not safe. Moreover, the website shows that although many landlords describe their extra top room as a whole floor apartment or a suite, that this is frequently an inaccurate description. Most of these rentals for one person do not include a kitchen. They frequently have no living room or other social space. The tenants only share a corridor with other roommates. To sum up, the low-income individual or family must endure poor housing for lower rent. Studio and room

\footnotetext{
${ }^{3}$ www.591.com.tw is a popular rental housing website in Taiwan.
} 
shared with other tenants are the most terrible choice for poor people because they have to take many restrictions. The most common instance is that they are forced to match the gender of other people in the room. This also includes a regional difference that Taipei and New Taipei City's rent are the highest with the smallest average space.

\section{Objective Quality of Life}

The content of quality of life is a concept which scholars have argued for a long time. Basically, quality of life has two dimensions, objective and subjective. This study focuses on objective quality of life. "Objective" quality of life is an estimation by external fair evaluation such as standard of living, income, education, health status and longevity (Netuveli and Blane, 2008). The Scandinavian "level of living" approach concentrates on objective life conditions. This includes economic resources (e.g., income and wealth) and non-economic resources (e.g., education and social relationships) (Erikson, 1974). This approach criticizes "subjective" measures of quality of life as invalid and incomparable. This is because of the possibility that a person can feel they have a worse life quality since they have experienced a downward movement, even if the movement is very slight. On the other hand, a person who has experienced terrible life quality for a long time might feel satisfied because of self-adjustment and self-comfort (Erikson, 1993).

According to Veenhoven's absolute theory (1988; 1991), objective measures of quality of life are better able to infer the basic needs of people. Absolute theory suggests that higher personal income is better able to meet the basic needs of humans such as health, food, and residence, and therefore a higher quality of life. The absolute socioeconomic approach is most useful for understanding the quality of life of people who are living below a certain level of well-being. If the individual's income is above a high income threshold, the influence of income on quality of life will be reduced. 
The data I use for this thesis includes many indicators of objective quality such as income, room area, household equipment, and household expenditures. Therefore, this study measures quality of life using objective measures such as income, expenditures, and housing conditions. Based on these theories above, this study assumes that we should be able to reveal poor people's financial and residential quality of life by analyzing their household equipment, expenditure, housing provision, and housing conditions.

\section{Relevant Research Indicator of Quality of Life}

Quality of life is an extensive, complicated topic. There are plentiful QOL studies using various indicators. This section will introduce several variables in this study that previous scholars have investigated.

Room area per capita is also discussed by many scholars as an indicator of QOL. For example, a study in urban America analyzed changes of the 1940-1970 Housing Census (Carnahan et al, 1974). A study of QOL in rural nursing homes in China also utilizes room space as one of the built environment factors to measure elders' QOL (Yu et al, 2017). Both demonstrate that room area or space is an important part of QOL.

Moreover, household equipment is also related to QOL. A study in Taiwan reported that those who have computers have a higher satisfaction on their quality of life than those who do not have computers. Also, this study found that internet users have no significant difference of overall quality of life compared to those who do not have internet (Liang et al, 2012). However, this study was published in 2012 and this situation may have changed in recent years. Relatedly, smartphones are another factor which affects quality of life. A study shows that people who have smartphones are more likely to find and track their health information than those who use regular cell phone; those who with a smartphone are also more likely to seek health information for caregivers than non-caregivers. Thus, the former experience a higher quality of life (Ghahramani et al, 2019). In addition, owning a car is a 
possible indicator of a high QOL. A study of health-related quality of life reported that having a car in the family is one of the positive components of a higher physical health component of quality of life (Noronha et al, 2016).

Expenditure is an indicator of quality of life is widely used. Although there are different theories about what a higher quality of life is, and how to measure quality of life, there is not much controversy that spending money to purchase desired goods is associated with a higher quality of life, at least up to a certain point. A study of health-related quality of life (HRQOL) found that those who have health insurance have a significantly higher HRQOL compared to those who do not have health insurance (Bharmal \& Thomas, 2005). Wong's study analyzing levels of expenditure of poor households in Hong Kong in 1990s. This study demonstrates the terrible situation of families who were affected by the 1997 Asian financial crisis (Wong, 2005). These studies all take expenditure as their research object. They all found that expenditure has relationship with quality of life.

\section{Relationship between Quality of Life and Age, Family Structure, and Income}

First of all, age is a common indicator while studying quality of life. There is abundant research on quality of life for specific age periods such as childhood (Davidson-Arad et al, 2003), adolescence (Wu, 2009; Wang et al, 2008), and elders (Li et al, 2014; Mukherjee \& Sadhna, 2016; Netuveli et al, 2002; Hsieh, 2004). Studies show that age affects quality of life in different ways during different stages of an individual's life course. People of different ages usually have distinctive sense of quality of life and happiness. For example, a study in Vietnam (Tran et al, 2018) shows that older people in the countryside are more sensitive to expenditure inequality. Thus, although this study is not targeting any specific age group, it is valuable to include age as a control variable for a study about QOL. Especially for an objective quality of life study, the age of the household head could be a factor that could affect household income, household expenditures, or housing provision. 
Second, family structure or family type is another indicator that is relevant to quality of life. For example, a study from India shows that in the domain of social relationships, quality of life scores were significantly higher for those living in nuclear families (Thadathil et al, 2015). A study in Pakistan asserts that older people who live in joint families had a better quality of life than those living in nuclear families (Naz et al, 2014). Another research in Japan shows that married couples were more likely to have severe hypertension compared to people in extended families (Turagabeci et al, 2007). Finally, Chao (2006) found that quality of life of single-parent families in Kaohsiung, Taiwan, is affected by manpower and social capital followed by economic capital and family relationship emotional capital. Family type is an important indicator for studying quality of life. Therefore, this thesis will also include family type as a control variable.

Last but not least, income is another important factor while investigating quality of life. Many studies illustrate the relationship between income and QOL. For example, a study in Taiwan reported that those who have higher household income and those who can balance between income and expenditure are more likely to have higher quality of life (Hsu, 2007). Netuveli's (2002) study shows that quality of life was reduced by poor perceived financial situation in the UK. A study in China asserts that income is positively and significantly influential when an individual is in a relatively lower financial situation (Xie, 2007). Thence, it is fair to include income as a control variable for this study.

\section{Housing Provision and Quality of Life}

In previous sections, we have discussed the housing provision and quality of life independently. In this part, we will talk about the relationship between these two concepts.

Housing provision and other housing dimensions such as housing environment, housing type and housing condition, are important for quality of life, especially for those impoverished. A study in Hong Kong shows that people with different income standards have 
different preferences for housing. For example, better locations and privacy are more important for low-income group while the medium and high-income groups have a greater desire for architectural quality (Gou et al, 2018). Nevertheless, housing condition and living environment are key issues in people's quality of life of different dimensions. For example, a study found that housing quality, includes housing provisions and other factors such as household equipment, have significant relationship with elders' psychological well-being. (Evans et al, 2002) Also, many studies discovered that health is affected by housing condition and housing provisions. Teariki (2017) found that migrants in New Zealand experience terrible rental housing condition which causes worse health condition. Another study (Lestan et al, 2014) found that housing condition, neighborhoods, housing types, and residential areas were related to people's health condition, especially among less educated poor people.

Moreover, some studies focus on analyzing the relationship between housing conditions and the quality of life. For example, a study (Nor et al, 2012) in Malaysia shows that physical dwelling conditions, housing type, housing provision, living environment and availability of amenities have a small, but significant and positive relationships between housing conditions, health, safety, and social support which give empirical evidence of the relationship between housing conditions and quality of life.

Moreover, housing satisfaction is a common dimension of quality of life. A study in Oklahoma analyzes the contribution of housing satisfaction to quality of life. Peck and Stewart (1985) found that higher housing satisfaction was accompanied by a significant increase in quality of life. They also found that higher housing satisfaction is related to higher neighborhood satisfaction, better structural quality, ownership, lower person-per-room ratios, more years in residence, and lower perceived housing cost. Homeownership is assumed to be preferred over renting because homeownership provides more security, more freedom, financial advantage and higher housing satisfaction. Elsinga and Hoekstra's study in 8 
European countries verified this theory (2005). The result shows that homeowners are more satisfied with their housing situation than tenants in 7 out of 8 countries. Homeowners and tenants demonstrate a similar level of housing satisfaction only in Austria. A study in China illustrates a similar result that homeownership has a significantly positive effect on housing satisfaction and overall happiness in urban China (Hu, 2013). Tan's (2012) study in Malaysia is another example where homeownership contributes to higher housing satisfaction. This study also values the importance of socio-economic determinants such as income. Moreover, a study for elders in Taiwan found that elders' income and their children's working conditions affect older people's housing choices. More specifically, those living alone and without employed children are more likely to sell their homes and rent a house for more living funds to maintain quality of life. Chen and Yang suggest that the government or related organizations could provide wealth management services for old people to improve elders' quality of life (Chen \& Yang, 2014).

To sum up, pieces of literature display a series of relationships. Housing conditions (including the major issue, housing provision, in this thesis) are important to housing satisfaction; housing satisfaction is a useful and common dimension of quality of life. Last but not least, age, income, family, and region (countries) are also linked with housing provision and quality of life.

\section{Official Definition of Low-Income and Middle-Low-Income Family in Taiwan}

In order to clarify the confusion in terminology, this section will explain the definition of the low-income and middle-low-income family system in Taiwan. In this thesis, the term, "low-income family," will specifically refer to this official definition in order to reduce misunderstanding of the data and studies in Taiwan.

Low-income and middle-low-income family are official identifications of whether a household has received a government allowance. The standard is based on "minimum living 
expenses"4 announced by local county governments. "Minimum living expenses" are announced every September by the local government. In order to be designated a low-income or middle-low-income family the following requirements must be met: (1) a low-income family must have a household income per capita below the minimum living expenses (announced by the local government each month); a middle-low-income family's household income per capita should be below 1.5 times the minimum living expenses; and (2) the value of the family property and wealth (e.g., cars, real estate, stocks, etc.) is below the limit announced by local governments for either low-income or middle-low-income families.

Low-income families and middle-low-income families are eligible for a "government allowance" that provides a number of benefits. These families received: (1) a subsidy of $70 \%$ to $100 \%$ of medical costs for sickness or injury; (2) a monthly rental allowance of up to NT $\$ 3,600$; (3) a tuition waiver of $100 \%$ for low-income families $\& 60 \%$ for middle-lowincome families, which includes all public and private schools under the Ministry of Education's regulation and education which is equal or higher to the high school level. The government also offers services to members of these families.

In addition, if the low-income or middle-low-income family applies for this government allowance, after receiving government employment services, finding a job after vocational training, or participating in poverty alleviation measures, the increased income and savings will not be calculated when the government is reviewing their qualification of low-income or middle-low-income family for next year. In other words, in these situations, the low-income or middle-low-income family will not lose their qualification, allowance, and other benefits if their income or property exceeds the statutory norms. Family can apply for this waiver annually, and for up to four years.

\footnotetext{
${ }^{4}$ The "minimum living expenses" is based on $60 \%$ of the median expenditure per capita last year announced by local governments refer from the expenditure data published by the Directorate-General of Budget, Accounting and Statistics, Executive Yuan, R.O.C. (Taiwan).
} 
Finally, children who are born after 2016 can apply to open a savings account. First, the government provides NT\$10,000 for the account opening. Second, as long as parents save money for their children in the account, the government will match that savings up to NT\$15,000 annually (this includes the NT\$10,000 for the account opening, so there is a ceiling of NT $\$ 15,000$ in the first year). After the children reach 18, they can withdraw the money for the children's education, business, or vocational training (Ministry of Health and Welfare, 2018).

\section{The Poverty Line in Taiwan}

The Taiwanese government uses a very low living expenditure to determine the definition of "poor." In lieu of a poverty line, households are defined as in poverty or near poor if they are categorized as low-income or middle-low-income families (Hung 2015). Consequently, Taiwan has the lowest official poverty rate in the world because of the restrictive definition of low-income and middle-low-income (中低收入, which means near poor) family. The second lowest country, Malaysia (3.8\%), has more than double the proportion of its poor population than Taiwan. Using this standard to discuss poverty in Taiwan is quite dangerous.

According to Hung (2015), the review process to qualify as a "low-income family" has three stages: (1) check who is in the household, (2) calculate household total income, and (3) calculate household property. ${ }^{5}$ The low-income family certificate needs to be renewed every year. If the income or property has shown a change that exceeds the standard, the family will be removed from the list. The rules seem simple. However, there are many problems in application. For example, it can be very difficult to prove who a person is living with or having contact with. There are two aspects to this issue that can be discussed. First, if a poor

\footnotetext{
${ }^{5}$ This process may be similar to qualify as a "middle-low income" (中低收入) household, but Hung (2015) does not address this in the research.
} 
family cannot prove separation from spouses, children, or parents, the officials will count their relatives' property and income as their household income. In many cases, separated but not divorced couples are a common barrier to applying for low-income family qualifications. It is also difficult to prove your parents are not going to help. Ironically, some wealthier people can misrepresent their situation. Thus, this is not merely a "qualification," but it is about the "ability" to apply for low-income family allowance.

In addition, when the government is calculating the family income, they will count the "expected income" for people who can work but who are not currently working. However, when the government is calculating the family property, they are using data from the "last tax year." The problem is that if a family collapsed suddenly, they may not qualify as a low- or middle-low-income household because they had some property on the record in the previous year, such as stock or real estate assets. On the other hand, a family that just rose from poverty may still be eligible to be categorized as low-income or middle-low-income because they did not have enough property on the record the previous year. Hung also criticizes the state government for not giving the local government access to the data. Apparently, the state intentionally wants to keep a stable and low number of low-income families.

Because the official poverty line in Taiwan is defined by $60 \%$ of the median expenditure per capita per month, it can be classified as a concept of relative poverty. In Taiwan's empirical research, some scholars also use relative poverty because it can reflect the life condition in different times and spaces. For example, Chen (2001) defines poverty as the lowest 20\% income families, and Zhu (1987) uses the poorest $5 \%$ of households. In 2011, a government report (Directorate General of Budget, Accounting and Statistics, Executive Yuan) used OECD's method (a poverty line based on the $50 \%$ of median of personal disposable income) and found the poverty rate was $7.7 \%$ in Taiwan in 2011 . Thus, in this 
thesis, I will define poor families as the poorest $10 \%$ of households since it is closer to the OECD's poverty line, compared to $20 \%$ or $5 \%$. 


\section{CHAPTER III: METHODOLOGY}

My central research question asks: How does housing provisions in Taiwan-such as whether a household owns their home, rents, or has an alternative arrangement —affect people's quality of life for the average Taiwanese household and for the families at the bottom decile of the household income distribution?" Based on the literature reviewed above, I test the following hypotheses in this research. I predict that the following hypotheses will be supported by the results from both the full sample and from those in the bottom decile of household income:

1. Those who own their homes without a mortgage will report greater room area per capita than will those who either own their homes with a mortgage or do not own their homes.

2. Those who own their homes without a mortgage will report higher scores on an index of household equipment than will those who either own their homes with a mortgage or do not own their homes.

3. Those who own their homes without a mortgage will report higher scores on an index of household expenditures than will those who either own their homes with a mortgage or do not own their homes.

\section{Data}

This study uses "Report the Survey of Family Income and Expenditure, 2018," which is a secondary quantitative dataset, collected by Directorate-General of Budget, Accounting and Statistics Executive Yuan, Republic of China (Taiwan). 


\section{Population/sample/units of the data}

This survey covers individuals residing in Taiwan and holding the citizenship of the Republic of China (Taiwan) and their families that lived together. People living in institutions and people who are serving in mandatory military which stay over six months in the same calendar year are excluded. The survey was undertaken annually, and the number of samples that had drawn were 16,528 households in 2018 (Report on the Survey of Family Income and Expenditure, 2018).

Based on the nature of statistics, the survey data uses "household" and "individual" as the statistical units. In this study, the household is the unit of analysis.

\section{Survey method of the data}

Data are collected both by interview survey and by diary survey.

a. Household heads to be interviewed: They are interviewed once a year, with inquiries designed to collect data on major items of annual income and expenditure.

b. Household heads required to do account-keeping: They are required to record all actual household expenditure item by item every day. Meanwhile, fieldworkers are required to do daily inspection on the households' daily entries in order to prevent mistakes and omissions.

c. In an interview, data mainly come from a respondent's memory that is subject to a restraint-discrepancy and omission. Data obtained from an interview are less accurate than those recorded on account books. However, account-keeping takes more manpower and money than an interview; therefore, extensive application of the account-keeping approach is impossible. Only a small number of households are selected both to do account-keeping and to receive an interview. From the same set of households, data obtained by these two approaches are compared, and results of the comparison are used to 
check and/or correct results of all interviews in the survey (Ministry of Health and Welfare, R.O.C.(Taiwan), 2019).

\section{Variables}

\section{Dependent variable}

In this study, financial and residential quality of life is the dependent variable, which includes three dimensions.

The first dimension is room area per capita (see Table 1), calculated as total room area in pings $^{6}$, which is a unit of area commonly used in Taiwan, divided by the total number of persons in the household.

Table 1

Data of Area per capita

\begin{tabular}{lllll}
\hline & \multicolumn{2}{l}{ All Taiwanese } & \multicolumn{2}{l}{ Bottom decile of household income } \\
& pings & sq. $\mathrm{ft}$ & pings & sq. $\mathrm{ft}$ \\
\hline minimum & 2 & 71.18 & 4 & 142.36 \\
maximum & 150 & $5,338.5$ & 140 & $4,982.6$ \\
mean & 18.5 & 659 & 29.9 & 1,064 \\
Md & 14.7 & 523 & 25 & 890 \\
SD & 13.36958 & 475.823 & 17.84504 & 635.1
\end{tabular}

The second dimension is household equipment (see Table 2), which includes internet, cell phone, personal computer, motorcycle, sedan vehicle, air conditioner, dehumidifier, water filter machine, vacuum cleaner, and an air purifier. Household equipment is recoded so that 0 indicates not possessing that type of equipment (e.g., there are no air-conditioners in the household) and 1 indicates possessing at least one unit of that type of equipment (e.g.,

\footnotetext{
${ }^{6} 1$ Taiwanese ping equal 35.59 square feet.
} 
there is at least one air-conditioner in the household). I constructed an additive index of these recoded variables to compute an overall score for each household's possession of equipment. Table 2

Data of Household Equipment

\begin{tabular}{lll}
\hline & All Taiwanese & Bottom decile of household income \\
\hline mean & 6.2453 & 3.4667 \\
Md & 6 & 3 \\
SD & 13.36958 & 2.06103
\end{tabular}

The third dimension is household expenditures (see Table 3). An additive index was computed to calculate household expenditures and includes food and non-alcoholic beverages; tobacco, alcoholic beverages and betel nuts; clothing and footwear; housing, water, electricity, gas and other fuels; health; transport; recreation and culture; education; restaurants and hotels; and miscellaneous goods and services.

Table 3

Data of Household Expenditures

\begin{tabular}{lll}
\hline & All Taiwanese & Bottom decile of household income \\
\hline minimum & NT\$52,374 & NT\$52,374 \\
maximum & NT\$6,989,019 & NT\$1,256,872 \\
mean & NT\$652,540.9013 & NT\$240,533.6973 \\
Md & 588,432 & 219,924 \\
SD & $383,385.5076$ & $113,307.2195$
\end{tabular}

\section{Independent variable}

In this study, the independent variable is housing provision (see Table 4), which includes the following: Homeowner with a mortgage; homeowner without a mortgage; owned by spouse, parents or children who are not living together; rented; allotted (the house is owned 
by firms, groups, schools, or government provided to the employees); and borrowed (borrowed from others without any cost; for example, retirees living in government dormitories) and others (besides the previous options). For only the bottom decile of household income, homeowner with a mortgage (the house is owned by a member who is usually living in the house and includes a mortgage); homeowner without a mortgage; owned by spouse, parents or children who are not living together; rented; allotted (the house is owned by firms, groups, schools, or government provided to the employees); and borrowed (borrowed from others without any cost; for example, retirees living in government dormitories) and others (besides the previous options). I constructed dummy variables for housing provision with "homeowner without a mortgage" serving as the reference category in my analyses.

Table 4

Distribution of Housing Provision

\begin{tabular}{lcccc}
\hline & \multicolumn{2}{c}{ All Taiwanese } & \multicolumn{2}{c}{ Bottom decile of income } \\
Housing Provision & Cases & Percentage & Cases & Percentage \\
\hline Homeowner with a mortgage & 2,715 & $16.4 \%$ & 36 & $2.2 \%$ \\
Homeowner without a mortgage & 11,238 & $68 \%$ & 1,307 & $79.1 \%$ \\
Family-owned & 784 & $4.7 \%$ & 92 & $5.6 \%$ \\
Tenant & 1,323 & $8.0 \%$ & 120 & $7.3 \%$ \\
Allotted & 35 & $0.2 \%$ & 1 & $0.1 \%$ \\
Borrowed and other & 433 & $2.6 \%$ & 96 & $5.8 \%$
\end{tabular}

\section{Control variables}

In this study, there are four control variables. First is age of household head (see Table $5)$. 
Table 5

Data of Age of Household Head

\begin{tabular}{lll}
\hline & All Taiwanese & Bottom decile of household income \\
\hline minimum & 16 & 18 \\
maximum & 101 & 101 \\
mean & 52.81 & 69.04 \\
Md & 52 & 69 \\
SD & 14.852 & 11.505
\end{tabular}

The second control variable is the number of persons in the household (see Table 6).

Table 6

Data of Number of persons

All Taiwanese Bottom decile of household income

\begin{tabular}{lll}
\hline minimum & 2 & 1 \\
maximum & 14 & 4 \\
mean & 3.04 & 1.42 \\
$\mathrm{Md}$ & 3.00 & 1.00 \\
$\mathrm{SD}$ & 1.471 & .555
\end{tabular}

The third control variable is type of family. For the purposes of this study, the following family types were included: single males; single females; married couple families (twoperson families) with a male household head; married couple families (two-person families) with a female household head; single parent families with a male household head; single parent families with a female household head; nuclear families with a male household head; nuclear families with a female household head; grandparents with grandchildren (parents absent) families with a male household head; grandparents with grandchildren (parents absent) families with a female household head $(n=95 ; 0.6 \%)$; three generations families with 
a male household head $(\mathrm{n}=1,903 ; 11.5 \%)$; and three generations families with a female household head $(\mathrm{n}=397 ; 2.4 \%)$. For only the bottom $10 \%$ decile of household income, single males $(n=359 ; 21.7 \%)$; single females $(n=643 ; 38.9 \%)$; married couple families (twoperson families) with a male household head $(\mathrm{n}=367 ; 22.2 \%)$; married couple families (twoperson families) with a female household head $(\mathrm{n}=113 ; 6.8 \%)$; single parent families with a male household head $(\mathrm{n}=30 ; 1.8 \%)$; single parent families with a female household head ( $\mathrm{n}$ $=55 ; 3.3 \%)$; nuclear families with a male household head $(\mathrm{n}=18 ; 1.1 \%)$; nuclear families with a female household head $(n=2 ; 0.1 \%)$; grandparents with grandchildren (parents absent) families with a male household head $(n=6 ; 0.4 \%)$; grandparents with grandchildren (parents absent) families with a female household head $(\mathrm{n}=17 ; 1 \%)$; three generations families with a male household head $(n=2 ; 0.1 \%)$; and three generations families with a female household head $(n=1 ; 0.1 \%)$. I constructed dummy variables for family type with "nuclear family with a male household head" serving as the reference category in my analyses. 
Table 7

Distribution of Type of Family

\begin{tabular}{|c|c|c|c|c|}
\hline \multirow[b]{2}{*}{ Type of Family } & \multicolumn{2}{|c|}{ All Taiwanese } & \multicolumn{2}{|c|}{ Bottom decile of income } \\
\hline & Cases & Percentage & Cases & Percentage \\
\hline Single males & 905 & $5.5 \%$ & 359 & $21.7 \%$ \\
\hline Single females & 1,247 & $7.5 \%$ & 643 & $38.9 \%$ \\
\hline Married couple/male head & 2,411 & $14.6 \%$ & 367 & $22.2 \%$ \\
\hline Married couple/female head & 701 & $4.2 \%$ & 113 & $6.8 \%$ \\
\hline Single parent $/$ male head & 740 & $4.5 \%$ & 30 & $1.8 \%$ \\
\hline Single parent/female head & 851 & $5.1 \%$ & 55 & $3.3 \%$ \\
\hline Nuclear/male head & 4,639 & $28.1 \%$ & 18 & $1.1 \%$ \\
\hline Nuclear/female head & 1,057 & $6.4 \%$ & 2 & $0.1 \%$ \\
\hline Grandparents/grandchildren/male head & 119 & $0.7 \%$ & 6 & $0.4 \%$ \\
\hline Grandparents/grandchildren/female head & 95 & $0.6 \%$ & 17 & $1 \%$ \\
\hline Three generations/male head & 1,903 & $11.5 \%$ & 2 & $0.1 \%$ \\
\hline Three generations/female head & 397 & $2.4 \%$ & 1 & $0.1 \%$ \\
\hline
\end{tabular}


The fourth control variable is household total income, which is total income minus imputed rental income (see Table 8; unit is New Taiwan Dollar).

Table 8

Household Income

\begin{tabular}{lll}
\hline & All Taiwanese & Bottom decile of household income \\
\hline minimum & 17,671 & 17,671 \\
maximum & $55,528,005$ & 362,459 \\
mean & $1,169,460.814$ & $256,132.5303$ \\
Md & 991,943 & 266,592 \\
SD & $960,805.1618$ & 71204.72998
\end{tabular}

\section{Analytical Strategy}

In this study, I conducted ordinary-least squares regression to answer my research question. First, I regressed room area per capita on the housing provision dummies with the control variables (age of household head, the number of household persons, the type of family dummies, and household total income). I also ran the ordinary-least squares regression model on the index of household equipment and then on the index of household expenditures. I ran additional OLS models on each household expenditure (e.g., food and non-alcoholic beverages) separately; these results are presented in the Appendix (Tables 5-A to 5-J). Finally, I ran all of the above regression models on just the lowest $10 \%$ of income families as well (the results for each household expenditure are presented in Tables 6-A to 6-J in the Appendix). 


\section{CHAPTER IV: RESULTS}

In the following paragraphs, I present the results of the OLS regression models.

In the first model, area per capita is regressed on the housing provision dummies with control variables (see Table 9). Controlling for all variables, I find that the residential quality of life (as measured by area per capita) is not statistically different between homeowners with mortgages and homeowners without mortgages and households living in family-owned properties, and that the other three categories (tenants, allotted, and other) have a higher residential quality of life compared to other means of house provisioning.

Specifically, the area per capita scores of homeowners with a mortgage and those in family-owned housing do not differ significantly from the area per capita score of those living in homeowner housing without a mortgage. Tenants and those living in allotted housing exhibit significantly lower area per capita scores compared to homeowners without a mortgage. The dummy of those living in "other" housing provisions attains significance; specifically, those living in this arrangement exhibit a lower area per capita score than that of homeowners without a mortgage. The number of persons in a household attains significance; as the number of persons increases, the area per capita score decreases. Most of the types of family dummies attain significance (recall that nuclear families with a male household head serve as the reference category in all models). Specifically, area per capita scores are significantly higher for the following types of families compared to the score for nuclear families with a male household head: adult male living alone, adult female living alone, married couples only with a male household head, married couples only with a female household head, single parent family with a male household head, single parent family with a female household head, grandparents with grandchildren family (parents absent) with a female head, and three generations family with a male head. Furthermore, the area per capita score is significantly lower for nuclear families with a female household head compared to 
the score for nuclear families with a male household head. The area per capita scores for grandparents with grandchildren (parents absent) with a male household head and for extended families with a female head do not significantly differ from the score for nuclear families with a male head. Finally, household income attains significance; as income increases, area per capita also increases. In addition, type of family (specifically, the dummies of single male and single female) are the strongest predictors of room area per capita, followed by number of persons in the household.

Next, I regress the index of household equipment on the housing provision dummies with the control variables (see Table 9). Controlling for all variables, I find that homeowners with mortgages have the highest quality of life, as measured by the index of household equipment, followed by homeowners without mortgages. Households with all other categories of house provisioning have a lower quality of life except comparing to those who live in allotted houses which have no significant differences.

Specifically, the household equipment score of those living in allotted housing does not differ significantly from the household equipment score of those living in homeowner housing without a mortgage. Those living in family-owned homes, tenants, and in other (including borrowed) types of housing exhibit significantly lower household equipment scores compared to those living as homeowners without a mortgage, whereas homeowners with a mortgage exhibit a higher household equipment index score than do homeowners without a mortgage. The age of household head attains significance; as the age of household head increases, the household equipment score decreases. The number of persons in a household also attains significance; as the number of persons increases, the household equipment scores also increase. All of the types of family dummies attain significance (recall that nuclear families with a male household head serve as the reference category in all models). Specifically, household equipment scores are significantly lower for all other types 
of families compared to the score for nuclear families with a male household head. Finally, household income attains significance; as income increases, household equipment also increases. Additionally, age of head of household is the strongest predictor of household equipment, followed by household income, and type of family (specifically, the dummies of single male and single female).

Next, I regress the index of total household expenditure on the housing provision dummies with the control variables (see Table 9). Controlling for all variables, I find that homeowners with mortgages have the highest quality of life, as measured by total household expenditure, followed by homeowners without mortgages. Households with all other categories of house provisioning have a lower quality of life.

Specifically, those living in family-owned homes, those who are tenants, those living in allotted housing, and those living in other housing provisions (including borrowed houses) have significantly lower total household expenditure scores compared to that of homeowners without a mortgage. The index score of total household expenditures of homeowners with a mortgage is significantly higher than the score of homeowners without a mortgage. The age of the household head attains significance; as age increases, the index scores of total household expenditure decreases. The number of persons in a household also attains significance; as the number of persons increases, the index scores of total household expenditure also increase. Finally, index scores of total household expenditures are significantly lower for all types of families compared to the score for nuclear families with a male household head with the exceptions of married couples only with a female household head and nuclear families with a female household head (the scores for these two family types do not significantly differ from the score of nuclear families with a male head). Finally, household income attains significance; as income increases, total household expenditure also 
increases. Moreover, household income is the strongest predictors of household expenditure, followed by number of persons in the household.

To summarize, when controlling for all variables, house provisioning has a significant effect on quality of life. Broadly, homeowners have the highest quality relative to other modes of house provisioning, with the possible exception that room area per capita for households living in family-owned housing. Intriguingly, homeowners with mortgages tend to have a higher quality of life than homeowners without mortgages. Recall that additional OLS models were run by regressing each household expenditure on the housing provision dummies and the control variables. The results of these models are presented in Tables 5-A to 5-J of the Appendix. 
Table 9

OLS Regression Models of Index of Room Area per Capita, Household Equipment and, Household Expenditures on Housing Provision

Dummies and Controls

\begin{tabular}{|c|c|c|c|c|c|c|}
\hline & Room Area & & Equipment & & Expenditure & \\
\hline Independent Variables & $\begin{array}{l}\mathrm{B} \\
(\mathrm{SE})\end{array}$ & Beta & $\begin{array}{l}\mathrm{B} \\
(\mathrm{SE})\end{array}$ & Beta & $\begin{array}{l}\mathrm{B} \\
(\mathrm{SE})\end{array}$ & Beta \\
\hline Homeowner w/o mortgage & & & ref & egory & & \\
\hline Homeowner w/mortgage & $\begin{array}{l}.040 \\
(.225)\end{array}$ & .001 & $\begin{array}{l}.630++ \\
(.038)\end{array}$ & .107 & $\begin{array}{l}69,014.576++ \\
(5,186.678)\end{array}$ & .067 \\
\hline Family-owned & $\begin{array}{l}.350 \\
(.380)\end{array}$ & .006 & $\begin{array}{l}-.338++ \\
(.064)\end{array}$ & -.033 & $\begin{array}{l}-25,080.108^{* *} \\
(8,778.032)\end{array}$ & -.014 \\
\hline Tenant & $\begin{array}{l}-6.324++ \\
(.300)\end{array}$ & -.128 & $\begin{array}{l}-.619++ \\
(.050)\end{array}$ & -.077 & $\begin{array}{l}-65,129.035++ \\
(6,935.283)\end{array}$ & -.046 \\
\hline Allotted & $\begin{array}{l}-8.329++ \\
(1.722)\end{array}$ & -.029 & $\begin{array}{l}0.087 \\
(.289)\end{array}$ & .002 & $\begin{array}{l}-98,445.372 * \\
(39,753.773)\end{array}$ & -.012 \\
\hline Other & $\begin{array}{l}-4.374++ \\
(.503)\end{array}$ & -.052 & $\begin{array}{l}-.762++ \\
(.084)\end{array}$ & -.056 & $\begin{array}{l}-60,158.538++ \\
(11,604.925)\end{array}$ & -.025 \\
\hline Age of household head & $\begin{array}{l}.010 \\
(.007)\end{array}$ & .011 & $\begin{array}{l}-.046++ \\
(.001)\end{array}$ & -.310 & $\begin{array}{l}-873.974++ \\
(150.205)\end{array}$ & -.034 \\
\hline
\end{tabular}




\begin{tabular}{|c|c|c|c|c|c|c|}
\hline Number of persons & $\begin{array}{l}-2.610++ \\
(.106)\end{array}$ & -.287 & $\begin{array}{l}.093++ \\
(.018)\end{array}$ & .063 & $\begin{array}{l}85,290.137++ \\
(2,446.775)\end{array}$ & .327 \\
\hline Single male & $\begin{array}{l}17.520++ \\
(.450)\end{array}$ & .298 & $\begin{array}{l}-1.109++ \\
(.076)\end{array}$ & -.116 & $\begin{array}{l}-44,850.612++ \\
(10,386.381)\end{array}$ & -.027 \\
\hline Single female & $\begin{array}{l}17.903++ \\
(.420)\end{array}$ & .354 & $\begin{array}{l}-1.231++ \\
(.070)\end{array}$ & -.149 & $\begin{array}{l}-32,196.045+ \\
(9,695.639)\end{array}$ & -.022 \\
\hline Married couple/male head & $\begin{array}{l}5.577++ \\
(.310)\end{array}$ & .147 & $\begin{array}{l}-.200++ \\
(.052)\end{array}$ & -.032 & $\begin{array}{l}-32,701.288++ \\
(7,154.133)\end{array}$ & -.030 \\
\hline Married couple/female head & $\begin{array}{l}5.346++ \\
(.444)\end{array}$ & .081 & $\begin{array}{l}-.173 * \\
(.075)\end{array}$ & -.016 & $\begin{array}{l}-17,560.61 \\
(10,259.429)\end{array}$ & -.009 \\
\hline Single parent $/$ male head & $\begin{array}{l}1.460++ \\
(.415)\end{array}$ & .023 & $\begin{array}{l}-.863++ \\
(.070)\end{array}$ & -.082 & $\begin{array}{l}-41,330.947++ \\
(9,586.841)\end{array}$ & -.022 \\
\hline Single parent/female head & $\begin{array}{l}1.870++ \\
(.390)\end{array}$ & .031 & $\begin{array}{l}-.535++ \\
(.065)\end{array}$ & -.054 & $\begin{array}{l}-25,816.724^{* *} \\
(9,003.760)\end{array}$ & -.015 \\
\hline Nuclear family/male head & & & & egory & & \\
\hline Nuclear family/female head & $\begin{array}{l}-.777^{*} \\
(.340)\end{array}$ & -.014 & $\begin{array}{l}-.183+ \\
(.057)\end{array}$ & -.020 & $\begin{array}{l}-969.372 \\
(7,844.604)\end{array}$ & -.001 \\
\hline $\begin{array}{l}\text { Grandparents/grandchildren } \\
\text { male head }\end{array}$ & $\begin{array}{l}.150 \\
(.944)\end{array}$ & .001 & $\begin{array}{l}-.716++ \\
(.158)\end{array}$ & -.028 & $\begin{array}{l}-77,929.067++ \\
(21,784.161)\end{array}$ & -.017 \\
\hline
\end{tabular}




\begin{tabular}{|c|c|c|c|c|c|c|}
\hline Grandparents/grandchildren & $2.356^{*}$ & .013 & $-.950++$ & -.033 & $-67,135.284 * *$ & -.013 \\
\hline female head & $(1.057)$ & & $(.177)$ & & $(24,399.193)$ & \\
\hline \multirow[t]{2}{*}{ Extended family/male head } & $.816^{*}$ & .019 & $-.431++$ & -.063 & $-54,292.430++$ & -.045 \\
\hline & $(.329)$ & & $(.055)$ & & $(7,587.523)$ & \\
\hline \multirow[t]{2}{*}{ Extended family/female head } & .780 & .009 & $-.497++$ & -.035 & $-43,532.695+$ & -.017 \\
\hline & $(.542)$ & & $(.091)$ & & $(12,511.494)$ & \\
\hline \multirow[t]{2}{*}{ Household income } & $9.749 \mathrm{E}-007++$ & .070 & $6.213 \mathrm{E}-007++$ & .273 & $.217++$ & .543 \\
\hline & $(.000)$ & & $(.000)$ & & $(.002)$ & \\
\hline \multirow[t]{2}{*}{ Constant } & 21.802 & & 7.965 & & $204,885.45$ & \\
\hline & $(.525)$ & & $(.088)$ & & $(12,126.106)$ & \\
\hline $\mathrm{r} 2=$ & .423 & & .391 & & .626 & \\
\hline \multirow[t]{2}{*}{$\mathrm{F}=$} & 637.871 & & 557.600 & & 1456.185 & \\
\hline & $\operatorname{sig}=.0001$ & & $\operatorname{sig}=.0001$ & & $\operatorname{sig}=.0001$ & \\
\hline
\end{tabular}


In the following paragraphs, I present the results of the same OLS regression models with variables for families in the lowest $10 \%$ of household income.

In the first model, area per capita is regressed on the housing provision dummies with the control variables (see Table 10). Controlling for all variables, I find that the residential quality of life (as measured by area per capita) is not statistically different between homeowners with mortgages and homeowners without mortgages and households living in family-owned properties, and that the other three categories (tenants, allotted, and other) have a higher residential quality of life compared to other means of house provisioning.

Specifically, tenants and those living in other (including borrowed) housing exhibit significantly lower area per capita scores compared to homeowners without a mortgage. Additionally, those living in allotted houses now exhibit significantly lower scores than do homeowners without a mortgage. Two of the type of family dummies attain significance. Specifically, area per capita scores are significantly higher for adult males living alone and adult females living alone compared to the score for nuclear families with a male household head. No other variables in the model attain significance. Additionally, type of family (specifically, the dummies of single male and single female) are the strongest predictors of room area per capita.

In the next model, household equipment is regressed on the housing provision dummies with the control variables (see Table 10). Controlling for all variables, I find that homeowners with mortgages have the highest quality of life, as measured by the index of household equipment. Households with some of the other categories of house provisioning have a lower quality of life except comparing to those who live in allotted houses which have no significant differences. Homeowners with mortgages and those who live in allotted houses report no significant difference compared to homeowners without a mortgage. 
Specifically, the household equipment score of homeowners with a mortgage does not differ significantly from the household equipment score of those living in homeowner housing without a mortgage. Those living in family-owned houses, those who are tenants, and those living in other (including borrowed) houses exhibit significantly lower household equipment scores compared to homeowners without a mortgage. The age of household head attains significance; as the age of household head increases, the household equipment scores decrease. Single parent families with male household heads exhibit a lower score on household equipment compared to that of nuclear families with a male household head. Conversely, three-generations families with a male household head have a higher score on household equipment compared to that of nuclear families with a male household head. Finally, household income attains significance; as income increases, household equipment also increases. Moreover, age of household head is the strongest predictors of household equipment.

I next regress the index of total household expenditure on the housing provision dummies for families at the bottom decile of household income with the control variables (see Table 10). Controlling for all variables, I find that homeowners with mortgages have the highest quality of life, as measured by total household expenditure, followed by homeowners without mortgages. Households with most of the other categories of house provisioning have a lower quality of life; those living in allotted housing report no significant difference.

Specifically, homeowners with a mortgage exhibit a higher score on the index of total household expenditures compared to the score of homeowners without a mortgage. Similarly, those living in family-owned homes, those who are tenants, and those living in other housing provisions (including borrowed houses) exhibit significantly lower scores on the index of total household expenditures compared to homeowners without a mortgage. The age of the household head attains significance; as age increases, scores on the index of total household 
expenditure decreases. The number of persons in a household also attains significance; as the number of persons increases, scores on the index of total household expenditures increase. Scores on the index of total household expenditures are significantly lower for single parent families with a male household head and significantly higher for nuclear families with a female head compared to the score for nuclear families with a male household head. Finally, household income attains significance; as income increases, scores on the index of total household expenditures also increase. In addition, number of persons is the strongest predictors of household expenditure, followed by age of household head.

To summarize, when controlling for all variables, house provisioning has a significant effect on quality of life. Broadly, homeowners have the highest quality relative to other modes of house provisioning, with the possible exception of room area per capita for households living in family-owned housing. The result of the bottom decile of household income demonstrates a similar outcome with models of all Taiwanese. However, different from the models of all Taiwanese people, the differences in quality of life between homeowners with or without mortgages are unapparent. Recall that additional OLS models were run by regressing each household expenditure on the housing provision dummies and the control variables for the bottom decile. The results of these models are presented in Tables 6-A to 6-J of the Appendix. 
Table 10

OLS Regression Models of Index of Room Area per Capita, Household Equipment and, Household Expenditures on Housing Provision

Dummies and Controls for the Bottom Decile of Household Income

\begin{tabular}{|c|c|c|c|c|c|c|}
\hline & Room Area & & Equipment & & Expenditure & \\
\hline Independent Variables & $\begin{array}{l}\text { B } \\
(\mathrm{SE})\end{array}$ & Beta & $\begin{array}{l}\mathrm{B} \\
(\mathrm{SE})\end{array}$ & Beta & $\begin{array}{l}\text { B } \\
(\mathrm{SE})\end{array}$ & Beta \\
\hline Homeowner w/o mortgage & reference ca & & & & & \\
\hline Homeowner w/mortgage & $\begin{array}{l}.850 \\
(2.692)\end{array}$ & .007 & $\begin{array}{l}.530 \\
(.300)\end{array}$ & .038 & $\begin{array}{l}40,686.279^{*} \\
(16,380.800)\end{array}$ & .052 \\
\hline Family-owned & $\begin{array}{l}-1.628 \\
(1.709)\end{array}$ & -.021 & $\begin{array}{l}-.671++ \\
(.191)\end{array}$ & -.075 & $\begin{array}{l}-32,177.681^{* *} \\
(10,399.032)\end{array}$ & -.065 \\
\hline Tenant & $\begin{array}{l}-11.949++ \\
(1.535)\end{array}$ & -.174 & $\begin{array}{l}-.968++ \\
(.171)\end{array}$ & -.122 & $\begin{array}{l}-61,109.307++ \\
(9338.957)\end{array}$ & -.140 \\
\hline Allotted & $\begin{array}{l}-31.931 * \\
(15.661)\end{array}$ & -.044 & $\begin{array}{l}-2.193 \\
(1.746)\end{array}$ & -.026 & $\begin{array}{l}-117,836.437 \\
(95,281.856)\end{array}$ & -.026 \\
\hline
\end{tabular}




\begin{tabular}{|c|c|c|c|c|c|c|}
\hline Other & $\begin{array}{l}-10.651++ \\
(1.697)\end{array}$ & -.140 & $\begin{array}{l}-1.301++ \\
(.189)\end{array}$ & -.148 & $\begin{array}{l}-66,505.029++ \\
(10,326.073)\end{array}$ & -.137 \\
\hline Age of household head & $\begin{array}{l}-.009 \\
(.037)\end{array}$ & -.006 & $\begin{array}{l}-.088++ \\
(.004)\end{array}$ & -.493 & $\begin{array}{l}-2199.116++ \\
(227.143)\end{array}$ & -.223 \\
\hline Number of persons & $\begin{array}{l}-4.580 \\
(2.718)\end{array}$ & -.143 & $\begin{array}{l}.316 \\
(.303)\end{array}$ & .085 & $\begin{array}{l}100,274.657++ \\
(16,536.279)\end{array}$ & .491 \\
\hline Single male & $\begin{array}{l}9.333 * \\
(4.672)\end{array}$ & .216 & $\begin{array}{l}-.319 \\
(.521)\end{array}$ & -.064 & $\begin{array}{l}26,181.307 \\
(28,421.038)\end{array}$ & .095 \\
\hline Single female & $\begin{array}{l}11.835 * \\
(4.637)\end{array}$ & .323 & $\begin{array}{l}-.270 \\
(.517)\end{array}$ & -.064 & $\begin{array}{l}43,019.316 \\
(28,210.715)\end{array}$ & .185 \\
\hline Married couple/male head & $\begin{array}{l}-.916 \\
(2.628)\end{array}$ & -.021 & $\begin{array}{l}.207 \\
(.293)\end{array}$ & .042 & $\begin{array}{l}7658.457 \\
(15,989.592)\end{array}$ & .028 \\
\hline Married couple/female head & $\begin{array}{l}-1.120 \\
(2.893)\end{array}$ & -.016 & $\begin{array}{l}.059 \\
(.323)\end{array}$ & .007 & $\begin{array}{l}32,470.869 \\
(17,601.604)\end{array}$ & .072 \\
\hline Single parent $/$ male head & -3.889 & -.029 & $-1.387+$ & -.090 & $-53,242.111^{*}$ & -.063 \\
\hline
\end{tabular}




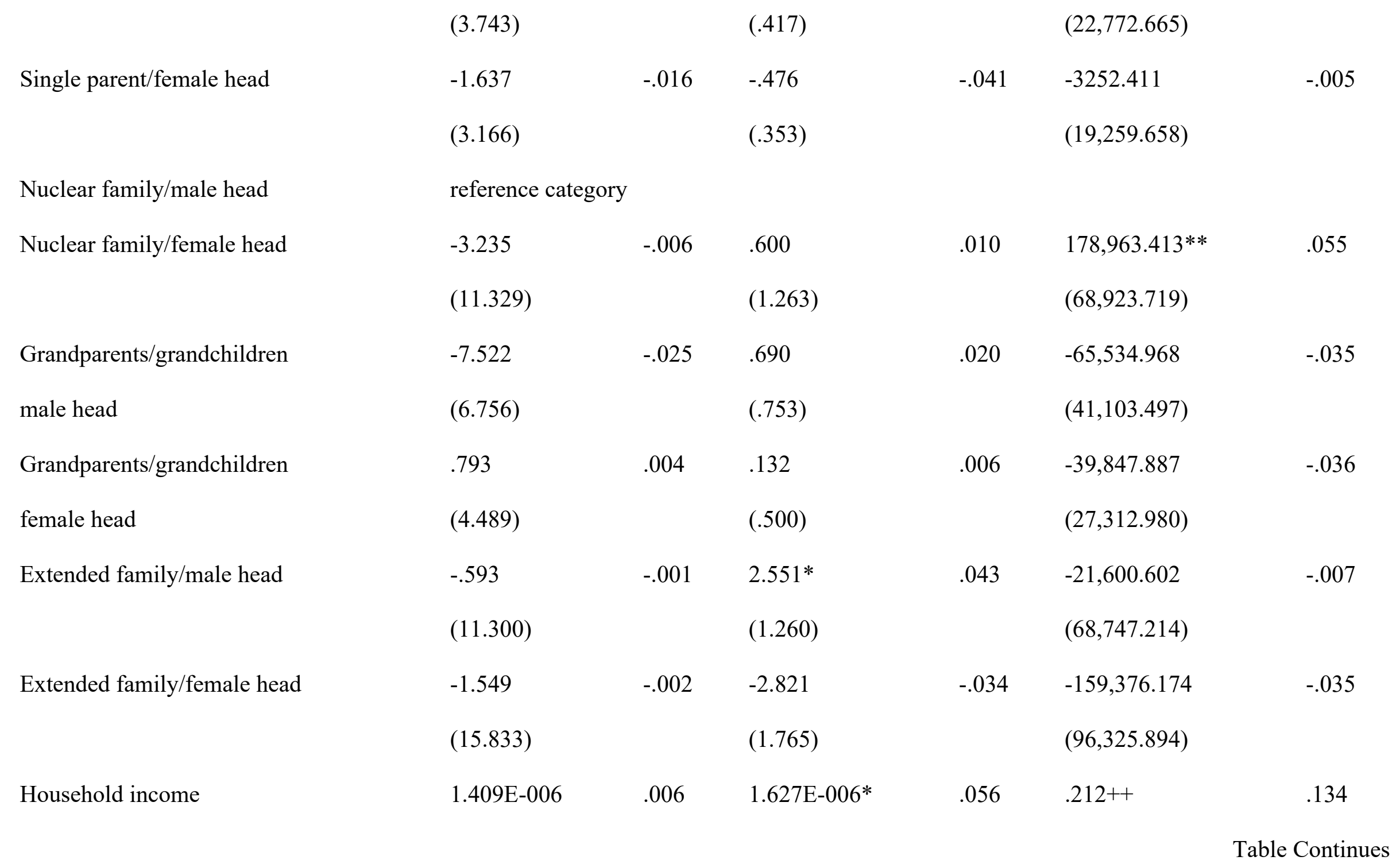




\begin{tabular}{|c|c|c|c|}
\hline & $(.000)$ & $(.000)$ & $(.036)$ \\
\hline \multirow[t]{2}{*}{ Constant } & 32.055 & 9.033 & $179,834.366$ \\
\hline & $(7.960)$ & $(.887)$ & $48,425.615$ \\
\hline $\mathrm{r} 2=$ & .245 & .297 & .307 \\
\hline \multirow[t]{2}{*}{$\mathrm{F}=$} & 27.937 & 36.283 & 38.094 \\
\hline & $\operatorname{sig}=.0001$ & $\operatorname{sig}=.0001$ & $\operatorname{sig}=.0001$ \\
\hline
\end{tabular}

$* \mathrm{p}<.05 ; * * \mathrm{p}<.01 ;+\mathrm{p}<.001 ;++\mathrm{p}<.0001$ 


\section{CHAPTER V: DISCUSSION AND CONCLUSION}

Recall that the first hypothesis states that those who own their homes without a mortgage will live in housing with more room area per capita than will those who either own their homes with a mortgage or those who do not own their homes. While we do not find a statistically significant difference between homeowners with and without mortgages, the results otherwise largely support this hypothesis in the models with the full sample and those with the bottom decile of household income. Specifically, compared to homeowners without mortgage, the dummies of those who are homeowners with a mortgage and those living in family-owned homes have no significant difference; those living in other household arrangements (tenants, allotted, and other) report significantly smaller room areas per capita than do homeowners without a mortgage. In other words, compared to most of those who do not own a house — regardless of whether they have an existing mortgage — those who are homeowners have larger room area per capita which indicate a higher quality of life.

The results in the models including only the bottom decile of household income is similar. Homeowners report significantly higher room area per capita scores than do those who are tenants or those who live in other housing provisions. Additionally, those who live in allotted houses report substantially smaller room area per capita scores than do homeowners. To sum up, the poorest decile of households who are homeowners (regardless of whether they have a mortgage) have larger room area per capita than those who are tenants and those who live in other forms of housing.

Larger room areas per capita is a strong indicator of quality of life. For example, people may enjoy more privacy, have more personal space, feel more comfortable, and are better able to avoid family conflict when it occurs. One possible reason why those living in familyowned housing have more room area per capita than do homeowners without a mortgage is probably that those people are living in areas which the housing prices are lower, so that 
people are more likely to own multiple houses. Therefore, those who live in family-owned houses are more likely living in houses with more area since the housing prices are cheaper. Moreover, in this study, there is no data of the age of houses or the region of the household. These are two possible factors may affect area of housing. For example, traditional housing in the countryside in Taiwan is typically large, along with the industrial transformation, population is outflowing from countryside to urban areas. Thus, those people who still live in rural areas are probably living in houses which were built for much larger families than in the past. On the other hand, perhaps the construction corporations have had different strategies in different time periods that housing ages likely demonstrate distinct pattern on the size of housing space. Although this study is unable to analyze these patterns, they are probably implicitly affecting the result.

The second hypothesis states that those who are homeowners without a mortgage possess more household equipment than do those who are homeowners with a mortgage or those who do not own their homes. This hypothesis was partially supported in the models including the full sample and those including only the bottom decile of household income. Specifically, in the model of the full sample, those living in family-owned homes, those who are tenants, and those who live in other forms of housing report lower scores on the index of household equipment than do homeowners without a mortgage (interestingly, homeowners with a mortgage report owning more household equipment than did homeowners without a mortgage). The "allotted" dummy variable has no significance; the other dummies retain significance. All in all, homeowners with a mortgage have more household equipment compared to homeowners without a mortgage and those who do not own a house.

In the model including only the bottom decile of household income, there is no statistical difference between homeowners who have a mortgage and those who don't. Those who live in family-owned houses, those who are tenants, and those living in other housing 
provisions have lower scores compared to homeowners. In other words, compared to most of those who do not own a house, those who are homeowners have more household equipment which indicates a higher quality of life.

More household equipment represents a higher quality of life. For instance, people who have an air-conditioner are more likely to experience a more comfortable indoor temperature during the summer, receive more information if they have internet access, have a higher quality of air or water if they have an air purifier or water filter machine, and experience more flexibility of transportation if they have a motorcycle or sedan vehicle. But why would homeowners without mortgages have less household equipment than homeowners with mortgages? This may reflect that households that have more recently purchased their home (and thus still have a mortgage) may be more willing to buy household equipment than do those who have purchased their homes earlier. The families who are still paying mortgages are the people who bought houses in recent years and may be more likely to invest money in equipment that increases the family's quality of life. For example, to respond to global warming and terrible air pollution, people nowadays are more likely to buy more airconditioners and air purifiers. This explanation is additionally supported by the finding that households with older household heads (irrespective of house provisioning) own less household equipment. Furthermore, this phenomenon is also possibly caused by regional differences; maybe people who live in urban areas have more desire to purchase household equipment. These explanations are merely speculative, however, and require additional research.

The third hypothesis states that those who are homeowners without a mortgage have higher household expenditures than do those who either own their homes with a mortgage or do not own their homes. The results confirm that homeowners have a higher quality of life than all other forms of housing provision, but once again the homeowners with mortgages 
have higher expenditures than those without mortgages. This pattern holds for both the full sample and those including only the bottom decile.

Higher expenditure scores mean that people spend more money for the family, which implies a higher quality of life. For example, they spend more money on education, health, entertainment, travel, or food. A possible speculation as to why those who are homeowners with a mortgage have higher household expenses than do homeowners without a mortgage is because they bought houses more recently. Therefore, they are more likely those who tend to spend more money to improve their quality of life further after they just settle a "home." Besides that, another speculation is that there is a regional difference that most of those who bought houses recently are living in areas with higher expense levels. My last supposition is that because there is a well-known cultural pressure in Taiwanese society that it is extremely important to give your child a real "home." Those families who are paying a mortgage are more likely the people who just got kids or planning to have a kid because Taiwanese people tend to NOT live in rental houses if they have children. According to Lin (2015), buying houses and having children are two factors having influences on each other. Therefore, I believe this is possible that those who own a house with a mortgage are more likely to spend more money in order to improve children's quality of life.

This study finds that housing provision is significantly related to financial and residential quality of life. The findings demonstrate several important phenomena. First, when compared to other groups, homeowners either with or without a mortgage typically spend more on all expenditure categories and have more household equipment, which indicates that they appear to have higher residential and financial quality of life. This finding applies to both the full sample as well as the poorest $10 \%$ of Taiwanese households. Interestingly, those families who have homeowner houses with a mortgage have a higher quality of life compared to those who have homeowner houses without a mortgage on two of 
the three indicators of quality of life (household expenditures and household equipment, but there is no statistically significant difference in size of residence). These results confirm those of earlier literature in Taiwan and internationally that those living in homeowner houses have higher residential and financial quality of life than do renters (Peck \& Stewart,1985; Elsinga \& Hoekstra, 2005; Hu, 2013; Tan, 2012; Chen \& Yang, 2014). However, it expands this finding by confirming that this is the case among the $10 \%$ lowest income households as well.

Second, tenants have a lower financial and residential quality of life compared to homeowners in Taiwan, after controlling for income, age and family structure. This finding supports the previous literature. For example, Hsueh and Chen's study (1998) found that homeowners were spending more money on things that can bring a higher quality of life such as household equipment, health, education, transportation, and entertainment compared to renters who were spending more on necessities such as food and clothing. This study also found that homeowners had higher spending on imputed rents than renters, which implies a higher quality of housing. This finding applies to the $10 \%$ lowest income households as well.

Third, a control variable used in this study — the age of household heads - has an unexpected and disturbing influence on the quality of life. As the age of household head increases, quality of life decreases, as measured by the lower household equipment and expenditure scores. However, due to the limitation of the dataset, further research is required in order to reveal the reason for this phenomenon.

Fourth, those living in a nuclear family with a male household head have a higher quality of life, as measured by higher scores on household equipment and expenditure. This shows a similar result as the study in India (Thadathil et al, 2015) in which nuclear families have a higher quality of life than alternative family structures.

In this study, I also discovered a very interesting phenomenon of homeownership rate among the bottom decile families in Taiwan. The data show that the bottom decile families 
have homeownership rate of $81.3 \%$ compared to $84.4 \%$ of all Taiwanese. Also, the percentage of renters is similar: and $7.3 \%$ in the bottom decile and $8.0 \%$ of all Taiwanese households. It is unexpected that those poor families have a similar homeownership rate with other people. However, homeowners among the bottom decile families are less likely to have a mortgage (2.2\% of the poorest $10 \%$, but $16.4 \%$ of the average Taiwanese household). To look at it another way, while $80.5 \%$ of homeowners in Taiwan do not have a mortgage, among the poorest $10 \%$ it is $97.3 \%$ of homeowners who do not have a mortgage. One interpretation of this finding is that the bottom decile of homeowners is more likely than the average Taiwanese to be living in an inherited house without a mortgage.

This study also demonstrates an unanticipated distinction between those categorized as "low income" by the government and the poorest decile of households. As mentioned above, the homeownership rate among the bottom decile is $81.3 \%$, however it is only $37.55 \%$ in 2018 among families categorized as "low-income families" (Ministry of Health and Welfare, R.O.C.(Taiwan), 2019). This leads to interesting questions that should be discussed in future research: do the bottom decile families actually have a similar economic status with the lowincome families in Taiwan? If so, do they have lower quality of life than the low-income families because they cannot receive the low-income-family allowance since they own a house?

The results of this study demonstrate an important idea that the quality of life of poor people (defined as the poorest 10\% of households in this study) improves by owning a house. Since Taiwan is a country with a highly commodified housing market, and the government has failed to reduce housing commodification, housing prices in Taiwan have continued to rise for a long time. In order to improve poor people's quality of life, I believe Taiwan should pursue three housing development strategies that focus on housing. First, since the housing vacancy rate is abnormally high in Taiwan, the government should introduce tax policies for 
vacant houses to increase the cost of holding multiple properties. Doing so should be able to reduce housing prices to provide more affordable houses.

Second, it would be beneficial if the government provided a subsidy or low-interest loans for poor people to buy houses. A program of housing subsidy and low-interest housing loans was introduced by the government around 1990 and was so popular that 248,561 loans had been approved by 2002 (Grange et al, 2006). This was a government program to respond to the rapidly increasing housing prices in the 1980s and the 1990s. In view of the recent high housing prices, the government is still providing similar program of low-interest loans and housing subsidies for people who do not own a house. However, the number of applicants has gradually declined because the housing prices have been rising so quickly that even with cheap credit, many poor people still cannot afford to purchase a home. Thus, the most critical issue is that the government should promote policies to inhibit speculation in the housing market. I assert that since the housing prices are overly high with an unusual housing vacancy rate, the housing commodification is overwhelmingly restricting Taiwanese people's right to housing consumption.

Third, housing commercialization is apparently a barrier for people who have the desire to have a home in Taiwan. Low-cost public housing for rent can be another solution. As I discussed in the literature review, public housing of the local government in Taiwan is under construction. However, the number of low-rent public housing units is insufficient. Especially in Taipei, the biggest city with the highest demand for housing, the extremely expensive land prices cause many difficulties for the government to build public houses. I recommend that the government of Taipei City try to cooperate with New Taipei City, the administrative district surrounding Taipei City, to build public housing in areas close to Taipei with lower land prices along with the development of public transportation. Moreover, the Taiwanese government should attempt to imitate countries following the road of the corporatist regime 
such as the Netherlands (Doling, 1999). For example, the excessive housing vacancy rate is needed to be addressed. The Taiwanese government should be trying to introduce these empty houses into the rental housing market to strengthen the competition between landlords.

There are several limitations of this study. First of all, the dataset does not include regional information. This means that I am unable to compare urban and rural areas in Taiwan, which could bias the results concerning room area per capita since rural areas are more likely to have larger room areas per capita than are urban areas. Second, the survey did not ask whether the respondent is living in a "low-income" or "middle-low-income" family. Thus, I am not able to compare the condition of the bottom decile households with those legally categorized as "low-income" families. As I mentioned in the previous sections, "lowincome family" refers to those who qualify as the official identification of people who live under the poverty line in Taiwan. It would be valuable if researchers could compare "lowincome family" and the bottom decile because Taiwan has the lowest poverty rate in the world. Many scholars have criticized for a long time that low-income households have too strict application qualifications in Taiwan (Hung 2015; Chen, 2001; Zhu, 1987). A third limitation is that study has examined quality of life using survey responses rather than ethnographic observation, and such survey responses only reveal a small piece of the whole picture. Ethnographic observation of poor people's real residential quality of life could reveal fundamental characteristics of residential quality of life such as level of cleanliness, brightness, messiness, or how the housing smells. Finally, to measure quality of life, it is important to include both subjective and objective aspects. However, this dataset only asked for objective information, which is insufficient to explain to what extent survey respondents are satisfied with their financial and residential status.

This study is a preliminary study of housing provision and quality of life. While I was conducting this research, I found that studies of housing provision are limited in Taiwan. In 
this era of high housing prices in Taiwan, it is important to investigate the housing condition, quality of life, and housing satisfaction. Future research should take housing prices into account since housing provision is significantly relevant to quality of life. Based on the results reported in this study, the Taiwanese government should pay more attention to strategies to reduce housing prices and increasing poor people's housing conditions and quality of life. 


\section{REFERENCES}

Bharmal, M., \& Thomas, J. (2005). Health insurance coverage and HEALTH-RELATED quality of Life: Analysis of 2000 medical Expenditure Panel survey data. Journal of Health Care for the Poor and Underserved, 16(4), 643-654. doi:10.1353/hpu.2005.0064

Brickman, P., Coates, D., \& Janoff-Bulman, R. (1978). Lottery winners and accident victims: Is happiness relative? Journal of Personality and Social Psychology, 36(8), 917-927. doi:10.1037/0022-3514.36.8.917

Chao, S. (2006). The Study of the Influence of Family Resources on the Single Parent Family Life Quality-Take Kaohsiung City as an Example. NTU Social Work Review, 13, 109171. doi:10.6171/ntuswr2006.13.03

Chen, C., \& Chang, Y. (2000). Relation and Interaction of Tenure Choice, Household Composition, and Household Savings-Evidence from Taiwanese Household Survey. Journal of Housing Studies, 9(2), 99-124. http://dx.doi.org/10.6375/JHS.200008.0099

Chen, J. (2001). Investigation on the Relative Poverty Rate of Female in Taiwan. The NCCU Journal of Sociology, 31, 113-137.

Chen, Li-Chun. (2008). The Past and the Future of Housing Policy. Community development journal quarterly. 121, 4-13.

Chen, S., \& Yang, I. (2014). Elderly Mobility, Housing Decisions and Economic Status in Taiwan. Journal of Property Management, 5(1), 61-76.

Chou, T. (1998). Crisis and dysfunction of Spatial development and management in Taiwan. Environment and Planning C: Government and Policy, 16(1), 69-84. doi:10.1068/c160069 
Davidson-Arad, B., Englechin-Segal, D., \& Wozner, Y. (2003). Short-term follow-up of children at risk: Comparison of the quality of life of children removed from home and children remaining at home. Child Abuse \& Neglect, 27(7), 733-750. doi:10.1016/s01452134(03)00113-3

Directorate-General of Budget, Accounting and Statistics, Executive Yuan (2019). The Survey of Family Income and Expenditure, 2018 (AA170043) [data file]. Available from Survey Research Data Archive, Academia Sinica. doi:10.6141/TW-SRDAAA170043-1

Doling, J, 1999 "Housing Policies and the Little Tigers: How Do They Compare with Other Industrialised Countries?" Housing Studies, 14(2): 229-250.

Doling, J. (1999). Housing policies and the little tigers: How do they compare with other industrialised countries? Housing Studies, 14(2), 229-250. doi:10.1080/02673039982939

Donnison, D. (1967) The Government of Housing (Harmondsworth: Penguin).

Drobnič, S., Beham, B., \& Präg, P. (2010). Good job, good life? Working conditions and quality of life in europe. Social Indicators Research, 99(2), 205-225. doi:10.1007/s11205-010-9586-7

EASTERLIN, R. A. (1974). Does economic growth improve the human lot? Some empirical evidence. Nations and Households in Economic Growth, 89-125. doi:10.1016/b978-0$12-205050-3.50008-7$

Elsinga, M., \& Hoekstra, J. (2005). Homeownership and housing satisfaction. Journal of Housing and the Built Environment, 20(4), 401-424. doi:10.1007/s10901-005-9023-4

Erikson, R. (1974). Welfare as a planning goal. Acta Sociologica, 17(3), 273-288. doi:10.1177/000169937401700305

Erikson, R. (1993). Descriptions of inequality: The Swedish approach to Welfare Research. The Quality of Life, 67-83. doi:10.1093/0198287976.003.0006 
Evans, G. W., Kantrowitz, E., \& Eshelman, P. (2002). Housing quality and psychological well-being among the elderly population. The Journals of Gerontology Series B: Psychological Sciences and Social Sciences, 57(4). doi:10.1093/geronb/57.4.p381

Ghahramani, F., \& Wang, J. (2019). Impact of smartphones on quality of life: A health information behavior perspective. Information Systems Frontiers, 22(6), 1275-1290. doi:10.1007/s10796-019-09931-z

Gou, Z., Xie, X., Lu, Y., \& Khoshbakht, M. (2018). Quality of Life (QoL) survey in Hong KONG: Understanding the importance of Housing environment and needs of residents from different Housing Sectors. International Journal of Environmental Research and Public Health, 15(2), 219. doi:10.3390/ijerph15020219

GRANGE, A. L., CHANG, C., \& YIP, N. M. (2006). Commodification and Urban development: A case study of Taiwan. Housing Studies, 21(1), 53-76. doi:10.1080/02673030500391114

Hsu, S. (2007). The Analyses of Family Quality of Life of Families with Young Children with Special Needs. Soochow Journal of Social Work, 17, 137-169. doi:10.29734/SJSW.200712.0005

Hsueh, L., \& Chen, H. (1998). A Comparison of Household Expenditure by Tenure ChoiceTaiwan Evidence. Journal of Housing Studies, 7, 21-40. doi:10.6375/JHS.199808.0021

Hsueh, L., Lin, C., \& Yen, C. (2009). The Effect of the Male Birth Cohort on Housing Tenure Choice and Housing Consumption in Taiwan. Journal of Housing Studies, 18(2), 69-92. doi:10.6375/JHS.200912.0069

Hu, F. (2011). Homeownership and Subjective wellbeing in URBAN CHINA: Does owning a house make you happier? Social Indicators Research, 110(3), 951-971. doi:10.1007/s11205-011-9967-6 
Hughes, M., \& Thomas, M. E. (1998). The continuing significance of RACE REVISITED: A study of race, class, and quality of life in America, 1972 to 1996. American Sociological Review, 63(6), 785-795. doi:10.2307/2657501

Hung, Ching-Shu. (2018). The Investigation of Minimum Wages'Rental Housing Affordability and Housing Environment in Six Cities. Retrieved from https://labor.ngo.tw/news/news-now/800-news20180726

Hung, P. (2015). Manufacture low-income family. Taipei: Socio Publishing.

Lan, C. I., \& Lee, C. (2020). Property-led renewal, state-induced RENT gap, and the sociospatial unevenness of Sustainable regeneration in Taipei. Housing Studies, 1-24. doi:10.1080/02673037.2020.1720615

Lestan, K., Eržen, I., \& Golobič, M. (2014). The role of open space in urban neighbourhoods for health-related lifestyle. International Journal of Environmental Research and Public Health, 11(6), 6547-6570. doi:10.3390/ijerph110606547

Li, Chia-Lin \& Hsieh, Wen-Jen. (2017). Determinants of Housing Tenure Choice in Taiwan: Gender Inequality and Regional Differences. Journal of Housing Studies, 26(1), 31-53

Li, J. (2021, March 6). Tainan City Youth Public Housing, target for 2,000 households. TSSDNEWS. Retrieved from https://tw.news.yahoo.com/\%E5\%8D\%97\%E5\%B8\%82\%E9\%9D\%92\%E5\%B9\%B4\% $\mathrm{E} 5 \% 85 \% \mathrm{AC} \% \mathrm{E} 5 \% \mathrm{AE} \% 85-$ \%E7\%9B\%AE\%E6\%A8\%992\%E5\%8D\%83\%E6\%88\%B6-141056537.html Li, Y., Lin, S., Fetzer, S. J., \& Chen, C. (2014). The relationships between activity and quality of life for older men and women at different ages in Taiwan. Journal of Women \& Aging, 26(3), 219-237. doi:10.1080/08952841.2014.888222 
Liang, T., Peng, J., \& Yu, C. (2011). A simpler quality of E-life indicator: Does the internet have a positive impact on the quality of life in Taiwan. Quality \& Quantity, 46(4), 10251045. doi:10.1007/s11135-011-9446-9

Liao, P., Fu, Y., \& Yi, C. (2005). Perceived quality of life in Taiwan and Hong Kong: An INTRA-CULTURE COMPARISON. Journal of Happiness Studies, 6(1), 43-67. doi:10.1007/s10902-004-1753-6

Lin, Pei-Syuan. (2015). The Relationship between House Buying and the Fertility Behavior of Households: Resource Exclusion and Motivated Stimulus. Journal of Housing Studies, Volume 24 No. 1, June 2015

Miller, E., \& Buys, L. (2008). Does social capital predict happiness, health, and life satisfaction in an urban AUSTRALIAN COMMUNITY? Kotuitui: New Zealand Journal of Social Sciences Online, 3(1), 15-20. doi:10.1080/1177083x.2008.9522429

Ministry of Health and Welfare, R.O.C.(Taiwan). (2019). Report of the Low-income and Middle-income Family Living Condition Survey 2018. Retrieved from https://dep.mohw.gov.tw/dos/cp-1768-43300-113.html

Ministry of Health and Welfare, R.O.C.(Taiwan). (2020). Regulations of Low-Income and Middle-Income family. Retrieved from https://www.mohw.gov.tw/cp-190-237-1.html

Mukherjee, A. J., \& Diwan, S. (2016). Late life immigration and quality of life among Asian Indian older adults. Journal of Cross-Cultural Gerontology, 31(3), 237-253. doi:10.1007/s10823-016-9294-0

Naz, S., Naz, S., \& Gul, S. (2014). Relationship between economic independence, social support and quality of life among elderly people. Journal of the Indian Academy of Applied Psychology, 40(2), 255. 
Netuveli, G. (2006). Quality of life at Older Ages: Evidence from the English longitudinal study of aging (wave 1). Journal of Epidemiology \& Community Health, 60(4), 357-363. doi:10.1136/jech.2005.040071

Netuveli, G., \& Blane, D. (2008). Quality of life in older ages. British Medical Bulletin, 85(1), 113-126. doi:10.1093/bmb/ldn003

Nickerson, C., Schwarz, N., \& Diener, E. (2007). Financial aspirations, financial success, and overall life satisfaction: Who? And how? Journal of Happiness Studies, 8(4), 467-515. doi:10.1007/s10902-006-9026-1

Noll, H. (2004). Social indicators and quality of Life Research: Background, achievements and current trends. Advances in Sociological Knowledge, 151-181. doi:10.1007/978-3663-09215-5_7

Noronha, D. D., Martins, A. M. E. D. B. L., Dias, D. D. S., Silveira, M. F., Paula, A. M. B. D., \& Haikal, D. S. A. (2016). Factors in adult health-related quality of life: a population-based study. Ciencia \& saude coletiva, 21, 463-474.

Pattillo, M. (2013). Housing: Commodity versus right. Annual Review of Sociology, 39(1), 509-531. doi:10.1146/annurev-soc-071312-145611

Peck, C., \& Kay Stewart, K. (1985). Satisfaction with housing and quality of life. Home Economics Research Journal, 13(4), 363-372. doi:10.1177/1077727X8501300403

Peng, C. (2004). The Relationship between Housing Rent and Price in Taiwan. City and Planning, 31(4), 391-412. doi:10.6128/CP.31.4.391

Peng, C. (2012). Relative Costs of Owning versus Renting and their Influence onHousing Tenure Choice. City and Planning, 39(1), 1-23. doi:10.6128/CP.39.1.1

Public Housing Project. (n.d.). Retrieved March 19, 2021, from https://www.hms.gov.taipei/\#!/ 
RONALD, R. (2007). Comparing homeowner societies: Can we construct an east-west model? Housing Studies, 22(4), 473-493. doi:10.1080/02673030701387614

Schuessler, K., \& Fisher, G. (1985). Quality of Life Research and Sociology. Annual Review of Sociology, 11, 129-149. Retrieved March 19, 2021, from http://www.jstor.org/stable/2083289

Shieh, W., \& Lin, S. (2000). The Tax Effect on Housing Tenure Choice in Taiwan. Journal of Housing Studies, 9(1), 1-17.

Teariki, M. (2017). Housing and health of Kiribati migrants living in New Zealand. International Journal of Environmental Research and Public Health, 14(10), 1237. doi:10.3390/ijerph14101237

Teck-Hong, T. (2012). Housing satisfaction in medium- and high-cost housing: The case of Greater Kuala Lumpur, Malaysia. Habitat International, 36(1), 108-116. doi:10.1016/j.habitatint.2011.06.003

Thadathil, S. E., Jose, R., \& Varghese, S. (2015). Assessment of domain wise quality of life among elderly population using WHO-BREF scale and its determinants in a rural setting of Kerala. International Journal of Current Medical and Applied Sciences, 7(1), 43-46.

Tran, T. Q., Nguyen, C. V., \& Van Vu, H. (2017). Does economic inequality affect the quality of life of older people in rural vietnam? Journal of Happiness Studies, 19(3), 781-799. doi:10.1007/s10902-017-9851-4

Turagabeci, A. R., Nakamura, K., Kizuki, M., \& Takano, T. (2007). Family structure and health, how companionship acts as a buffer against ill health. Health and Quality of Life Outcomes, 5(1), 61. doi:10.1186/1477-7525-5-61

Veenhoven, R. (1988). The utility of happiness. Social indicators research, 20(4), 333-354. Veenhoven, R. (1991). Is happiness relative?. Social indicators research, 24(1), 1-34. 
Wang, E. S. T., Chen, L. S. L., Lin, J. Y. C., \& Wang, M. C. H. (2008). The relationship between leisure satisfaction and life satisfaction of adolescents concerning online games. Adolescence, 43(169), 177-184.

Wang, N., Liu, F., Huang, C., \& Chang, Y. (n.d.). Who needs social housing? Journal of Housing Studies, 29(2), 99-129. doi:10.6375/JHS

Wang, Y. T. (2005). The Phenomenon of Poverty in Taiwan: A Review of Research. NTU Social Work Review (10), 1-54. Doi: 10.6171/ntuswr2005.10.01

Wen, S. C. (1989). A cross-national study on housing development in Asian transitional countries: Hong Kong, Korea (South), Singapore and Taiwan (The Republic of China).

Wong, H. (2005). The quality of life of HONG KONG'S poor households in the 1990S: Levels of expenditure, income security and poverty. Social Indicators Research, 71(13), 411-440. doi:10.1007/s11205-004-8030-2

Wu, C. H. (2009). Enhancing quality of life by shifting importance perception among life domains. Journal of Happiness Studies, 10(1), 37-47.doi: 10.1007/s10902-007-9060-7

Wu, W., \& Hsu, C. (2004). Housing Tenure Choices of Single-Head Households. City and Planning, 31(4), 325-340. doi:10.6128/CP

Yeh, H. (2014). Job demands, JOB resources, and job satisfaction in East Asia. Social Indicators Research, 121(1), 47-60. doi:10.1007/s11205-014-0631-9

Yeh, H. (2014). Quality of Life Research: Measurement, Theory, and Analysis. Journal of State and Society, 16, 1-40. doi:10.30174/JSS

Zainal, N. R., Kaur, G., Ahmad, N. ‘, \& Khalili, J. M. (2012). Housing conditions and quality of life of the urban poor in Malaysia. Procedia - Social and Behavioral Sciences, 50, 827-838. doi:10.1016/j.sbspro.2012.08.085 
Zamfir, E. (2017). Quality of life and social justice in Romania: Measuring quality of life. Revista de Cercetare şi Intervenţie Socială, (58), 34-53.

Zhu, Y. (1987). Talking about the causes and solutions of poverty in our country. Wunsing, $113,88-93$. 


\section{APPENDIX A: TABLES FOR ALL SAMPLES}

Table 11

OLS Regression Models of Food and Non-Alcoholic Beverages Expenditure on Housing

Provision Dummies and Controls

Independent Variables $\quad \underline{B} \quad \underline{B e t a}$

$(\mathrm{SE})$

Homeowner without mortgage

reference category

Homeowner w/mortgage

$-8,191.889++\quad-.045$

$(1,018.541)$

Family-owned

$\begin{array}{ll}-8870.738++ & -.028\end{array}$

$(1,723.798)$

Tenant

$-10,345.135++\quad-.042$

$(1,361.926)$

Allotted

$-20,160.557 * * \quad-.014$

$(7,806.701)$

Other

$\begin{array}{ll}-8,213.725++ & -.019\end{array}$

$(2,278.933)$

Age of household head

$210.102++$

.046

(29.497)

Number of persons

$28,324.784++$

.619

(480.489)

Adult male living alone

$$
\begin{gathered}
-16,338.591++\quad-.055 \\
(2,039.640)
\end{gathered}
$$

Table Continues 
Adult female living alone

Married couple/male head

Married couple/female head

Single parent/male head

Single parent/female head

Nuclear family/male head

Nuclear family/female head

Grandparents/grandchildren-

Male head

Grandparents/grandchildren-

Female head

Extended family/male head

Extended family/female head

Household income

$$
\begin{gathered}
-6,686.231++ \\
(1,903.994)
\end{gathered}
$$$$
-.026
$$

$4,356.099 * *$

$(1,404.903)$

$6,027.759 * *$

.018

$(2,014.709)$

$-8,669.353++$

$(1,882.629)$

$-5,437.482 * * \quad-.018$

$(1,768.126)$

reference category

$3,335.577^{*}$

0.012

$(1,540.495)$

$2,397.284$

0.003

$(4,277.894)$

608.274

0.001

$(4,791.425)$

$4,053.437 * *$

0.019

$(1,490.010)$

2,173.941

0.005

$(2,456.962)$
$0.011++$
0.155

(.000) 
Constant

$9,926.051$

$(2,381.281)$

$\mathrm{r}^{2}=.533$

$\mathrm{F}=990.671 \quad \mathrm{sig}=.0001$

$* \mathrm{p}<.05 * * \mathrm{p}<.01+\mathrm{p}<.001++\mathrm{p}<.0001$ 
Table 12

OLS Regression Models of Tobacco, Alcoholic Beverages and Betel Nuts Expenditure on Housing Provision Dummies and Controls

Independent Variables

$\underline{B}$

(SE)

Homeowner without mortgage

Homeowner w/mortgage

496.725

.010

$(410.514)$

Family-owned

231.779

.003

$(694.761)$

Tenant

$3,383.849++$

.048

$(548.912)$

Allotted

$-5,572.596$

$-.013$

$(3,146.420)$

Other

$1,531.257$

.013

(918.503)

Age of household head

$-18.184$

$-.014$

(11.888)

Number of persons

$2,014.506++$

.155

(193.657)

Adult male living alone

$5,537.230++$

.066

$(822.058)$

Adult female living alone $-4,592.664++\quad-.063$

(767.388) 
Married couple/male head

(566.233)

Married couple/female head

$-883.989$

(812.010)

Single parent/male head

$4,433.338++$

(758.777)

Single parent/female head

$-5,885.197++\quad-.068$

(712.627)

Nuclear family/male head

reference category

Nuclear family/female head

$-3,569.573++$

$-.046$

(620.882)

Grandparents/grandchildren-

Male head

$-1,632.786$

$-.007$

$(1,724.167)$

Grandparents/grandchildren-

$-6,855.039++$

Female head

$(1,931.140)$

Extended family/male head

698.485

.012

(600.535)

Extended family/female head

$-5,103.932++$

(990.256)

Household income

$.001++$

(.000)

Constant

$3,668.291$

959.754

Table Continues 
$\mathrm{r}^{2}=.060$

$\mathrm{F}=55.012 \quad \operatorname{sig}=.0001$

$* \mathrm{p}<.05 * * \mathrm{p}<.01 \quad+\mathrm{p}<.001 \quad++\mathrm{p}<.0001$ 
Table 13

OLS Regression Models of Clothing and Footwear Expenditure on Housing Provision

Dummies and Controls

Independent Variables

$\underline{\mathrm{B}}$

$\underline{\text { Beta }}$

(SE)

Homeowner without mortgage

reference category

Homeowner w/mortgage

$1,094.789 * * \quad .019$

(357.338)

Family-owned

$\begin{array}{ll}-1,947.826+ & -.020\end{array}$

(604.765)

Tenant

$-3,117.700++\quad-.040$

(477.808)

Allotted

$-3,813.156$

$-.008$

$(2,738.847)$

Other

$-2,866.737++$

(799.525)

Age of household head

$-97.318++\quad-.068$

(10.348)

Number of persons

$3,333.405++$

.231

(168.571)

Adult male living alone

$-336.827$

$-.004$

(715.573)

Adult female living alone

$2,385.222++$

.030

(667.984)

Table Continues 
Married couple/male head

(492.886)

Married couple/female head

$-626.494$

$-.006$

(706.826)

Single parent/male head

$-2,333.688++$

(660.488)

Single parent/female head

$1,127.602$

.012

(620.317)

Nuclear family/male head

reference category

Nuclear family/female head

737.066

.009

(540.456)

Grandparents/grandchildren-

Male head

$-4,459.453 * *$

$-.018$

$(1,500.826)$

Grandparents/grandchildren-

$-1,001.864$

Female head

$(1,680.989)$

Extended family/male head

$-3,493.969++$

$-.053$

(522.745)

Extended family/female head

$-4,810.397++$ $-.035$

(861.983)

Household income

$.011++$

(.000)

Constant

$5,442.021$

(835.431) 
$r^{2}=.419$

$\mathrm{F}=627.422 \quad \operatorname{sig}=.0001$

$* \mathrm{p}<.05 * * \mathrm{p}<.01 \quad+\mathrm{p}<.001 \quad++\mathrm{p}<.0001$ 
Table 14

OLS Regression Models of Housing, Water, Electricity, Gas and Other Fuels Expenditure on Housing Provision Dummies and Controls

Independent Variables

$\underline{\mathrm{B}}$

$\underline{\text { Beta }}$

(SE)

Homeowner without mortgage

Homeowner w/mortgage

$30,587.701++$

.177

$(2,189.748)$

Family-owned

$-7,489.618^{*}$

$-.040$

$(3,705.971)$

Tenant

$-29,789.252++$

$(2,927.986)$

Allotted

$-80,711.135++$

$(16,783.525)$

Other

$$
-30,369.324++\quad-.075
$$

$(4,899.448)$

Age of household head

$-206.841+$

(63.415)

Number of persons

$2,544.770 *$

.033

$(1,032.997)$

Adult male living alone

$\begin{array}{ll}-33,391.235++ & -.068\end{array}$

$(4,384.995)$

Adult female living alone

$(4,093.373)$ 
Married couple/male head

$\begin{array}{ll}-5,477.205 & -.017\end{array}$

$(3,020.382)$

Married couple/female head

625.481

.001

$(4,331.397)$

Single parent/male head

$-15,323.393++\quad-.028$

$(4,047.439)$

Single parent/female head

$-6,729.701$

$-.013$

$(3,801.270)$

Nuclear family/male head

reference category

Nuclear family/female head

$12,659.202++$

.028

$(3,311.890)$

Grandparents/grandchildren-

$-17,361.224$

$-.013$

Male head

$(9,196.989)$

Grandparents/grandchildren-

$-17,073.029$

Female head

$(10,301.021)$

Extended family/male head

$-14,825.247++$

$-.042$

$(3,203.353)$

Extended family/female head

$-12,680.834^{*}$

$(5,282.189)$

Household income

$.042++$

$(.001)$

Constant

$151,847.779$

$(5,119.484)$

$\mathrm{r}^{2}=.220$

Table Continues 


$$
\mathrm{F}=244.392 \quad \operatorname{sig}=.0001
$$

$* \mathrm{p}<.05 * * \mathrm{p}<.01+\mathrm{p}<.001++\mathrm{p}<.0001$ 
Table 15

OLS Regression Models of Health Expenditure on Housing Provision Dummies and Controls Independent Variables $\underline{\text { B }} \quad \underline{\text { Beta }}$

$\underline{(\mathrm{SE})}$

Homeowner without mortgage reference category

Homeowner w/mortgage

$5,031.907++\quad .066$

$(528.959)$

Family-owned

$-1,848.766^{*} \quad-.014$

(895.221)

Tenant

$-5,498.176++$ $-.053$

(707.289)

Allotted

$4,925.729$

.008

$(4,054.257)$

Other

$-3,834.635+$

$-.022$

$(1,183.519)$

Age of household head

$-198.580++$

$-.104$

(15.319)

Number of persons

4,991.674++

(249.532)

Adult male living alone

$-1,207.856$

$-.010$

$(1,059.247)$

Adult female living alone

324.976

.003

(988.802)

Table Continues 
Married couple/male head

Married couple/female head

Single parent/male head

Single parent/female head

Nuclear family/male head

Nuclear family/female head

Grandparents/grandchildren-

Male head

Grandparents/grandchildren-

Female head

Extended family/male head

Extended family/female head

Household income
$-3,180.216++$

(729.609)

$-3,792.638++$

$(1,046.300)$

$-3,403.208+$

$-.025$

(977.706)

$-2,364.535 * *$

$-.018$

(918.241)

reference category

$-1,078.843$

$-.009$

(800.026)

$-9,438.742++$

$-.028$

$(2,221.641)$

$-6,397.135^{* *}$

$(2,488.333)$

$-4,843.443++$ $-.054$

(773.808)

$-5,074.682++$

$(1,275.975)$

$$
.009++
$$

Constant

$10,497.070$

$(1,236.671)$

$\mathrm{r}^{2}=.290$ 


$$
\mathrm{F}=355.614 \quad \operatorname{sig}=.0001
$$

$* \mathrm{p}<.05 * * \mathrm{p}<.01+\mathrm{p}<.001++\mathrm{p}<.0001$ 
Table 16

OLS Regression Models of Transport Expenditure on Housing Provision Dummies and Controls

$\underline{\text { Independent Variables }}$

$\underline{\mathrm{B}}$

(SE)

Homeowner without mortgage

Homeowner w/mortgage

$10,394.653++$

.027

$(2,878.961)$

Family-owned

$-10,451.509^{*}$

$-.016$

$(4,872.410)$

Tenant

$-12,105.855^{* *}$

$(3,849.557)$

Allotted

$-7,206.347$

$-.002$

$(22,066.069)$

Other

Age of household head

$-421.228++$

(83.374)

Number of persons

$2,772.096^{*}$

.029

$(1,358.128)$

Adult male living alone

600.731

.001

$(5,765.153)$

Adult female living alone

$-7,526.999$

$-.014$

$(5,381.744)$ 
Married couple/male head

Married couple/female head

Single parent/male head

Single parent/female head

Nuclear family/male head

Nuclear family/female head

Grandparents/grandchildren-

Male head

Grandparents/grandchildren-

Female head

Extended family/male head

Extended family/female head

Household income

Constant

$\mathrm{r}^{2}=.157$

$$
-1,215.500
$$

$-.003$

$(3,971.034)$

$$
1,689.145
$$

$(5,694.686)$

$$
-3,434.422
$$

$(5,321.354)$

$$
-9,534.810
$$

$(4,997.704)$

reference category

$$
\begin{array}{cc}
-11,810.849 * * & -.020 \\
(4,354.293) &
\end{array}
$$

$$
-18,405.845 \quad-.011
$$

$(12,091.702)$

$-16,230.597 \quad-.009$

$(13,543.224)$

$-3,262.123 \quad-.007$

$(4,211.596)$

$3,905.845$

.004

$(6,944.736)$

$.052++$ .356 


$$
\mathrm{F}=161.779 \quad \operatorname{sig}=.0001
$$

$* \mathrm{p}<.05 * * \mathrm{p}<.01+\mathrm{p}<.001++\mathrm{p}<.0001$ 
Table 17

OLS Regression Models of Recreation and Culture Expenditure on Housing Provision

Dummies and Controls

Independent Variables

B $\quad$ Beta

(SE)

Homeowner without mortgage

reference category

Homeowner w/mortgage

$1,825.104 \quad .010$

$(1,223.983)$

Family-owned

$\begin{array}{ll}-7,973.985++ & -.026\end{array}$

$(2,071.491)$

Tenant

$-10,792.412++\quad-.045$

$(1,636.629)$

Allotted

$-2,184.226$

$-.002$

$(9,381.328)$

Other

$-9,287.926+\quad-.023$

$(2,738.598)$

Age of household head

$-106.373 * *$

(35.446)

Number of persons

$-1,452.141 * \quad-.032$

(577.404)

Adult male living alone

$-7,175.107 * * \quad-.025$

$(2,451.039)$

Adult female living alone

$-1,065.771 \quad-.004$

$(2,288.034)$

Table Continues 
Married couple/male head

$(1,688.274)$

Married couple/female head

$4,383.918$

.013

$(2,421.080)$

Single parent/male head

$-8,668.403++$

$(2,262.359)$

Single parent/female head

$-1,975.896$

$(2,124.760)$

Nuclear family/male head

reference category

Nuclear family/female head

8,127.795++

.030

$(1,851.216)$

Grandparents/grandchildren-

$-6,431.837$

$-.008$

Male head

$(5,140.754)$

Grandparents/grandchildren-

$-4,783.513$

Female head

$(5,757.864)$

Extended family/male head

$-7,614.187++$

$(1,790.548)$

Extended family/female head

$-5,573.448$

$(2,952.535)$

Household income

$.037++$

$(.001)$

Constant

$15,923.904$

$(2,861.590)$

$\mathrm{r}^{2}=.293$ 


$$
\mathrm{F}=359.861 \quad \operatorname{sig}=.0001
$$

$* \mathrm{p}<.05 * * \mathrm{p}<.01+\mathrm{p}<.001 \quad++\mathrm{p}<.0001$ 
Table 18

OLS Regression Models of Education Expenditure on Housing Provision Dummies and Controls

$\underline{\text { Independent Variables }}$

$\underline{\mathrm{B}}$

$\underline{\text { Beta }}$

$(\mathrm{SE})$

Homeowner without mortgage

Homeowner w/mortgage

$13,934.271++\quad .092$

$(1,086.036)$

Family-owned

$9,644.921++$

.036

$(1,838.028)$

Tenant

$1,175.161$

.006

$(1,452.176)$

Allotted

$11,990.459$

.010

$(8,324.023)$

Other

$5,287.424^{*}$

.015

$(2,429.950)$

Age of household head

$134.590++$

.035

$(31.451)$

Number of persons

$17,414.710++$

.454

(512.329)

Adult male living alone

$8,140.996++$

.033

$(2,174.799)$

Adult female living alone

$(2,030.165)$ 
Married couple/male head

Married couple/female head

Single parent/male head

Single parent/female head

Nuclear family/male head

Nuclear family/female head

Grandparents/grandchildren-

Male head

Grandparents/grandchildren-

Female head

Extended family/male head

Extended family/female head

Household income

Constant

$\mathrm{r}^{2}=.242$ $-11,749.949++\quad-.074$

$(1,498.000)$

$-11,001.389++\quad-.039$

$(2,148.217)$

$-3,623.361 \quad-.013$

$(2,007.384)$

$5,943.982 * * \quad .023$

$(1,885.293)$

reference category

$-10,695.857++\quad-.046$

$(1,642.578)$

116.279

.000

$(4,561.375)$

$4,226.488$

.006

$(5,108.935)$

$-14,240.564++\quad-.081$

$(1,588.748)$

$-7,683.509 * * \quad-.021$

$(2,619.776)$

$.008++$

$(.000)$

$-40,030.359$

$(2,539.080)$

Table Continues 


$$
\mathrm{F}=277.007 \quad \mathrm{sig}=.0001
$$

$* \mathrm{p}<.05 * * \mathrm{p}<.01+\mathrm{p}<.001++\mathrm{p}<.0001$ 
Table 19

OLS Regression Models of Restaurants and Hotels Expenditure on Housing Provision

Dummies and Controls

Independent Variables

$\underline{\mathrm{B}}$

$\underline{\text { Beta }}$

(SE)

Homeowner without mortgage

reference category

Homeowner w/mortgage

$13,391.292++\quad .067$

$(1,164.897)$

Family-owned

$3,655.104$

.010

$(1,971.494)$

Tenant

$5,804.428++$

.021

$(1,557.623)$

Allotted

$8,780.371$

.005

$(8,928.461)$

Other

$1,076.713$

.002

$(2,606.397)$

Age of household head

$\begin{array}{ll}-309.097++ & -.062\end{array}$

(33.735)

Number of persons

$25,014.724++$

.495

(549.531)

Adult male living alone

$8,723.259++$

.027

$(2,332.719)$

Adult female living alone

$-1,512.744 \quad-.005$

$(2,177.583)$

Table Continues 
Married couple/male head

Married couple/female head

Single parent/male head

Single parent/female head

Nuclear family/male head

Nuclear family/female head

Grandparents/grandchildren-

Male head

Grandparents/grandchildren-

Female head

Extended family/male head

Extended family/female head

Household income

$$
\begin{gathered}
-9,675.138++ \\
(1,606.776)
\end{gathered}
$$

$-9,263.153++$ $-.025$

$(2,304.207)$

$6,094.840 * *$

$(2,153.148)$

466.023

.001

$(2,022.191)$

reference category

$-1,952.469$

$-.006$

$(1,761.851)$

$-24,047.003++\quad-.027$

$(4,892.593)$

$-15,724.016^{* *} \quad-.016$

$(5,479.914)$

$-17,958.181++\quad-.077$

$(1,704.113)$

$-16,558.319++\quad-.034$

$(2,810.007)$

$.024++$ .316

Constant

$13,035.858$

$(2,723.451)$

$\mathrm{r}^{2}=.499$ 


$$
\mathrm{F}=865.022 \quad \operatorname{sig}=.0001
$$

${ }^{*} \mathrm{p}<.05 * * \mathrm{p}<.01+\mathrm{p}<.001 \quad++\mathrm{p}<.0001$ 
Table 20

OLS Regression Models of Miscellaneous Goods and Services Expenditure on Housing Provision Dummies and Controls

Independent Variables

B $\quad$ Beta

(SE)

Homeowner without mortgage

reference category

Homeowner w/mortgage

$450.022 \quad .003$

$(1,076.982)$

Family-owned

$-29.471$

.000

$(1,822.705)$

Tenant

$-3,843.943 * * \quad-.019$

$(1,440.069)$

Allotted

$-4,493.914$

$-.004$

$(8,254.629)$

Other

357.897

.001

$(2,409.692)$

Age of household head

$138.954++$

.038

(31.189)

Number of persons

331.609

.009

(508.058)

Adult male living alone

$-9,403.211++$ $-.040$

$(2,156.669)$

Adult female living alone

$-2,958.322$

$-.015$

$(2,013.240)$

Table Continues 
Married couple/male head

Married couple/female head

Single parent/male head

Single parent/female head

Nuclear family/male head

Nuclear family/female head

Grandparents/grandchildren-

Male head

Grandparents/grandchildren-

Female head

Extended family/male head

Extended family/female head

Household income
$-4,762.197+$

$-.031$

$(1,485.512)$

$-4,719.253^{*} \quad-.018$

$(2,130.308)$

$-6,403.296+$

$-.025$

$(1,990.649)$

$-1,426.708$

$-.006$

$(1,869.576)$

reference category

$3,278.578^{*} \quad .015$

$(1,628.884)$

$1,334.261$

.002

$(4,523.348)$

$-3,904.853$

$(5,066.344)$

7,193.362++

.043

$(1,575.503)$

$7,872.640 * *$

.022

$(2,597.935)$

$.022++$

(.000)

Constant

$3,772.319$

(2,517.912)

$\mathrm{r}^{2}=.180$

Table Continues 


$$
\mathrm{F}=190.545 \quad \mathrm{sig}=.0001
$$

$* \mathrm{p}<.05 * * \mathrm{p}<.01+\mathrm{p}<.001++\mathrm{p}<.0001$ 
APPENDIX B: TABLES FOR THE BOTTOM DECILE OF HOUSEHOLD INCOME

Table 21

OLS Regression Models of Food and Non-Alcoholic Beverages Expenditure on Housing Provision Dummies and Controls (Bottom Decile of Household Income)

Independent Variables

$\underline{B}$

$\underline{B e t a}$

$(\mathrm{SE})$

Homeowner without mortgage

reference category

Homeowner w/mortgage

745.679

.182

$(4,091.855)$

Family-owned

$-4,205.010$

$-1.619$

$(2597.635)$

Tenant

$-12,493.829++\quad-5.356$

$(2,332.832)$

Allotted

$-2,097.732$

$-.088$

$(23,801.009)$

Other

$-8,088.398 * *$

$-3.136$

$(2,579.410)$

Age of household head

72.977

1.286

(56.739)

Number of persons

$33,693.547++$

$(4,130.693)$

Adult male living alone

$-6,316.589$

$-.890$

$(7,099.456)$

Table Continues 
Adult female living alone

Married couple/male head

Married couple/female head

Single parent/male head

Single parent/female head

Nuclear family/male head

Nuclear family/female head

Grandparents/grandchildren-

Male head

Grandparents/grandchildren-

Female head

Extended family/male head

Extended family/female head

Household income
$2,681.454$

$(7,046.919)$

$2,843.351$

.712

$(3,994.133)$

$5,664.244$

1.288

$(4,396.807)$

$-11,055.086$

$-1.943$

$(5,688.516)$

$1,859.263$ $-.386$

$(-4,810.982)$

reference category

$-36,273.420 *$

$-.040$

$(17,216.857)$

$$
428.173
$$

(10267.482)

$5,283.818 \quad-.017$

$(6,822.668)$

$1,018.875$

.011

$(17,172.766)$

$65,364.004 * * \quad-.050$

$(24,061.805)$

$.030+$

.067

(.009)

Table Continues 
Constant

$-2,174.931$

$12,096.516$

$r^{2}=.456$

$\mathrm{F}=71.861 \quad$ sig $=.0001$

$* \mathrm{p}<.05 * * \mathrm{p}<.01 \quad+\mathrm{p}<.001 \quad++\mathrm{p}<.0001$ 
Table 22

OLS Regression Models of Tobacco, Alcoholic Beverages and Betel Nuts Expenditure on Housing Provision Dummies and Controls (Bottom Decile of Household Income)

Independent Variables

$\underline{\mathrm{B}}$

$(\mathrm{SE})$

Homeowner without mortgage

Homeowner w/mortgage

$1,646.617$

.022

$(1,801.115)$

Family-owned

433.903

.009

$(1,143.403)$

Tenant

$1,531.499$

.036

$(1,026.845)$

Allotted

$4,137.046$

.009

$(10,476.509)$

Other

$-662.056$

$-.014$

$(1,135.381)$

Age of household head

$-71.287 * *$

$-.075$

(24.975)

Number of persons

$-3,418.222$

$-.174$

$(1,818.211)$

Adult male living alone

$-3,939.051$

$(3,124.974)$

Adult female living alone

$$
\begin{array}{cc}
-11,413.426++ & -.510 \\
(3,101.848) &
\end{array}
$$


Married couple/male head

$-5,747.150+$

$(1,758.101)$

Married couple/female head

$-2,572.827$

$-.060$

$(1,935.346)$

Single parent/male head

$-.019$

$(2,503.919)$

Single parent/female head

Nuclear family/male head

Nuclear family/female head

Grandparents/grandchildren-

Male head

Grandparents/grandchildren-

Female head

Extended family/male head

Extended family/female head

Household income

Constant

$\mathrm{r}^{2}=.097$
$-6,696.370 * * \quad-.110$

$(2,117.654)$

reference category

$-859.973-.003$

$(7,578.358)$

$-3,696.145 \quad-.020$

$(4,519.446)$

$-9,157.000 * * \quad-.085$

$(3,003.139)$

3,126.799 $\quad .010$

$(7,558.951)$

$\begin{array}{ll}-8,384.654 & -.019\end{array}$

$(10,591.304)$

.006

.040
$18,956.202$

$(5,324.533)$

Table Continues 
$\mathrm{F}=9.207 \quad \mathrm{sig}=.0001$

$* \mathrm{p}<.05 * * \mathrm{p}<.01+\mathrm{p}<.001++\mathrm{p}<.0001$ 
Table 23

OLS Regression Models of Clothing and Footwear Expenditure on Housing Provision

Dummies and Controls (Bottom Decile of Household Income)

Independent Variables

B $\quad$ Beta

$(\mathrm{SE})$

Homeowner without mortgage

reference category

Homeowner w/mortgage

461.493

.013

(796.674)

Family-owned

$-961.029$

$-.043$

$(505.753)$

Tenant

$-2,365.569++$

(454.197)

Allotted

$-5,099.268$

$-.025$

$(4,633.999)$

Other

$-1,822.436++$

$-.084$

(502.205)

Age of household head

$-102.778++$

(11.047)

Number of persons

3,132.219++ .341

(804.236)

Adult male living alone

$2,492.258$

.201

$(1,382.247)$

Adult female living alone

$3,779.415^{* *}$ .361

$(1,372.018)$ 
Married couple/male head

Married couple/female head

Single parent/male head

Single parent/female head

Nuclear family/male head

Nuclear family/female head

Grandparents/grandchildren-

Male head

Grandparents/grandchildren-

Female head

Extended family/male head

Extended family/female head

Household income

$$
\text { (856.048) }
$$

$-180.592-.005$

$(1,107.540)$

908.471

.032

(936.687)

reference category

$22,085.154++$

$(3,352.080)$

345.661

.004

$(1,999.054)$

$$
747.103
$$

$$
(1,328.357)
$$

$-3,871.831 \quad-.026$

$(3,343.496)$

$-12,929.658 * * \quad-.062$

$(4,684.775)$

$.009++$

$(.002)$

Constant

$3,343.522$

(2,355.162)

$\mathrm{r}^{2}=.192$ 


$$
\mathrm{F}=20.455 \quad \operatorname{sig}=.0001
$$

$* \mathrm{p}<.05 * * \mathrm{p}<.01+\mathrm{p}<.001++\mathrm{p}<.0001$ 
Table 24

OLS Regression Models of Housing, Water, Electricity, Gas and other fuels Expenditure on Housing Provision Dummies and Controls (Bottom Decile of Household Income)

Independent Variables

$\underline{\mathrm{B}}$

$(\mathrm{SE})$

Homeowner without mortgage

Homeowner w/mortgage

$13,604.621$

.035

$(9,489.134)$

Family-owned

$-14,847.504 *$

$-.059$

$(6,023.992)$

Tenant

$-29,964.344++$

$(5,409.908)$

Allotted

$-93,524.978$

$-.040$

$(55,195.248)$

Other

$-36,774.200++$

$(5,981.728)$

Age of household head

$-596.911++$

(131.580)

Number of persons

$10,895.100$

.105

$(9,579.201)$

Adult male living alone

$-8,688.687$

$-.062$

$(16,463.851)$

Adult female living alone .067

$(16,342.014)$ 
Married couple/male head

$(9,262.514)$

Married couple/female head

$$
8,635.951
$$

.038

$(10,196.326)$

Single parent/male head

$$
-24,810.106
$$

$(13,191.839)$

Single parent/female head

$-9,211.057$

$(11,156.811)$

Nuclear family/male head

reference category

Nuclear family/female head

$36,119.055$

.022

$(39,926.403)$

Grandparents/grandchildren-

$-37,596.837$

$-.039$

Male head

$(23,810.595)$

Grandparents/grandchildren-

$-23,887.659$

Female head

$(15,821.970)$

Extended family/male head

$-62,690.426$

$-.038$

$(39,824.156)$

Extended family/female head

$-51,097.998$

$(55,800.043)$

Household income

$.090++$

Constant

$113,334.436$

$(28,052.181)$

$\mathrm{r}^{2}=.097$

Table Continues 


$$
\mathrm{F}=9.211 \quad \operatorname{sig}=.0001
$$

$* \mathrm{p}<.05 * * \mathrm{p}<.01+\mathrm{p}<.001++\mathrm{p}<.0001$ 
Table 25

OLS Regression Models of Health Expenditure on Housing Provision Dummies and Controls (Bottom Decile of Household Income)

Independent Variables

$\underline{\mathrm{B}}$

$\underline{\text { Beta }}$

$(\mathrm{SE})$

Homeowner without mortgage

Homeowner w/mortgage

$3,150.895^{*}$

.054

$(1,383.762)$

Family-owned

$-807.561$

$-.022$

(878.455)

Tenant

$$
\begin{gathered}
-3,249.677++ \\
(788.905)
\end{gathered}
$$$$
-.098
$$

Allotted

$-7,182.874$

$-.021$

$(8,048.901)$

Other

$$
-1,277.910
$$

(872.291)

Age of household head

$$
-193.077++
$$

(19.188)

Number of persons

$11,636.047++$ .751

$(1,396.896)$

Adult male living alone

$11,803.681++$ .566

$(2,400.857)$

Adult female living alone

$13,770.834++$ .781

$(2,383.090)$ 
$(1,350.715)$

Married couple/female head

$2,332.651$

.068

$(1,486.889)$

Single parent/male head

$-535.364$

$-.008$

$(1,923.713)$

Single parent/female head

$3,412.648^{*}$

.071

$(1,626.953)$

Nuclear family/male head

reference category

Nuclear family/female head

$-4,882.022$

$-.020$

$(5,822.307)$

Grandparents/grandchildren-

$-9,464.511 * *$

$-.066$

Male head

$(3,472.204)$

Grandparents/grandchildren-

$3,647.518$

Female head

$(2,307.254)$

Extended family/male head

$-14,583.418^{*}$

$-.059$

$(5,807.397)$

Extended family/female head

$-17,207.717^{*}$

$(8,137.096)$

Household income

.000

.001

(.003)

Constant

$-8,963.722$

$(4,090.737)$

$\mathrm{r}^{2}=.142$

Table Continues 


$$
\mathrm{F}=14.222 \quad \mathrm{sig}=.0001
$$

$* \mathrm{p}<.05 * * \mathrm{p}<.01+\mathrm{p}<.001++\mathrm{p}<.0001$ 
Table 26

OLS Regression Models of Transport Expenditure on Housing Provision Dummies and Controls (Bottom Decile of Household Income)

Independent Variables

$\underline{\mathrm{B}}$

$\underline{\text { Beta }}$

$(\mathrm{SE})$

Homeowner without mortgage

Homeowner w/mortgage

$7,093.162$

.038

$(4,439.807)$

Family-owned

$-5,502.140$

$-.046$

$(2,818.525)$

Tenant

$-10,159.699++\quad-.096$

$(2,531.205)$

Allotted

$-14,694.290$

$-.013$

$(25,824.934)$

Other

$-7,929.397 * * \quad-.068$

$(2,798.751)$

Age of household head

$-596.943++$

$(61.564)$

Number of persons

$13,041.894 * *$

.264

$(4,481.948)$

Adult male living alone

$12,005.222$

.181

$(7,703.161)$

Adult female living alone

$9,643.857$

.172

$(7,646.155)$

Table Continues 
Married couple/male head

$(4,333.775)$

Married couple/female head

$9,871.561^{*}$ .091

$(4,770.691)$

Single parent/male head

$-5,859.699$

$(6,172.241)$

Single parent/female head

$$
-292.083
$$

$(5,220.085)$

Nuclear family/male head reference category

Nuclear family/female head

42,083.063*

$(18,680.897)$

Grandparents/grandchildren$4,524.633$ .010

Male head

$(11,140.579)$

Grandparents/grandchildren-

$-1,474.540$ $-.005$

Female head

$(7,402.835)$

Extended family/male head

$12,196.886$

.015

$(18,633.057)$

Extended family/female head

$-40,373.819$ $-.036$

$(26,107.907)$

Household income

.015

.038

(.010)

Constant

$27,306.389$

$(13,125.146)$

$\mathrm{r}^{2}=.130$ 


$$
\mathrm{F}=12.846 \quad \operatorname{sig}=.0001
$$

$* \mathrm{p}<.05 * * \mathrm{p}<.01+\mathrm{p}<.001++\mathrm{p}<.0001$ 
Table 27

OLS Regression Models of Recreation and Culture Expenditure on Housing Provision

Dummies and Controls (Bottom Decile of Household Income)

Independent Variables

$\underline{B} \quad$ Beta

$(\mathrm{SE})$

Homeowner without mortgage

reference category

Homeowner w/mortgage

$1,202.972 \quad .010$

$(3,010.222)$

Family-owned

$-3,857.186 *$

$-.049$

$(1,910.981)$

Tenant

$-6,346.373++$

$(1,716.176)$

Allotted

$-9,006.808$

$-.012$

$(17,509.495)$

Other

$-5,315.086^{* *}$

$(1,897.573)$

Age of household head

$-212.955++$

$(41.741)$

Number of persons

$1,509.819$

.047

$(3,038.794)$

Adult male living alone

$2,138.833$

.049

$(5,222.799)$

Adult female living alone

$(5,184.149)$ 
Married couple/male head

$$
6,707.336^{*}
$$

$(2,938.331)$

Married couple/female head

$7,188.591 *$

$(3,234.563)$

Single parent/male head

$-2,717.493$

$-.020$

$(4,184.825)$

Single parent/female head

$-791.342$

$-.008$

$(3,539.256)$

Nuclear family/male head

reference category

Nuclear family/female head

$64,836.070++$

.126

$(12,665.785)$

Grandparents/grandchildren-

$-828.217$

$-.003$

Male head

$(7,553.395)$

Grandparents/grandchildren-

$3,722.118$

Female head

$(5,019.177)$

Extended family/male head

$-727.673$

$-.001$

$(12,633.349)$

Extended family/female head

$-12,741.373$

$(17,701.353)$

Household income

.010

$(.007)$

Constant

$17,195.750$

$(8,898.946)$

$\mathrm{r}^{2}=.065$

Table Continues 
$\mathrm{F}=5.963 \quad \operatorname{sig}=.0001$

$* \mathrm{p}<.05 * * \mathrm{p}<.01+\mathrm{p}<.001++\mathrm{p}<.0001$ 
Table 28

OLS Regression Models of Education Expenditure on Housing Provision Dummies and Controls (Bottom Decile of Household Income)

Independent Variables

$\underline{\mathrm{B}}$

$\underline{\text { Beta }}$

$(\mathrm{SE})$

Homeowner without mortgage

Homeowner w/mortgage

$3,790.038^{*}$

.054

$(1,572.620)$

Family-owned

$1,416.169$

.032

(998.347)

Tenant

945.655

.024

(896.576)

Allotted

$-1,073.908$

$-.003$

$(9,147.425)$

Other

$-336.208$

$-.008$

(991.343)

Age of household head

$-40.715$

$-.046$

(21.807)

Number of persons

$15,847.833++$

.866

$(1,587.547)$

Adult male living alone

$19,122.212++$ .776

$(2,728.529)$

Adult female living alone

$19,376.512++$

.930

$(2,708.337)$ 
Married couple/male head

Married couple/female head

Single parent/male head

Single parent/female head

Nuclear family/male head

Nuclear family/female head

Grandparents/grandchildren-

Male head

Grandparents/grandchildren-

Female head

Extended family/male head

Extended family/female head

Household income

Constant

$r^{2}=.207$
$(1,535.062)$

$3,312.482 *$

.082

$(1,689.822)$

$4,373.914 *$

$(2,186.264)$

$16,544.023++$

$$
(1,849.001)
$$

reference category

$-13,279.526^{*}$

$-.045$

$(6,616.943)$

$7,730.277^{*}$

.046

$(3,946.094)$

$15,686.893++$

.156

$(2,622.151)$

$46,126.331++$ .158

$(6,599.998)$

$-11,967.730$

$(9,247.657)$

.001

.007

(.003)

$-32,665.964$

$(4,649.046)$

Table Continues 


$$
\mathrm{F}=22.355 \quad \operatorname{sig}=.0001
$$

$* \mathrm{p}<.05 * * \mathrm{p}<.01+\mathrm{p}<.001++\mathrm{p}<.0001$ 
Table 29

OLS Regression Models of Restaurants and Hotels Expenditure on Housing Provision

Dummies and Controls (Bottom Decile of Household Income)

Independent Variables

B $\quad$ Beta

$(\mathrm{SE})$

Homeowner without mortgage

reference category

Homeowner w/mortgage

$8,675.148^{*}$

.054

$(3,539.709)$

Family-owned

$-493.371$

$-.005$

$(2,247.116)$

Tenant

$3,768.579$

.042

$(2,018.045)$

Allotted

$6,479.630$

.007

$(20,589.353)$

Other

$-774.321$

$-.008$

$(2,231.350)$

Age of household head

$-491.232++$

(49.083)

Number of persons

$17,485.334++$

.416

$(3,573.307)$

Adult male living alone

$12,801.471 *$

.226

$(6,141.471)$

Adult female living alone

$4,802.225$

.100

$(6,096.023)$

Table Continues 
Married couple/male head

Married couple/female head

Single parent/male head

Single parent/female head

Nuclear family/male head

Nuclear family/female head

Grandparents/grandchildren-

Male head

Grandparents/grandchildren-

Female head

Extended family/male head

Extended family/female head

Constant

$\mathrm{r}^{2}=.238$
$-1,724.531 \quad-.031$

$(3,455.173)$

$4,466.034$

.048

$(3,803.511)$

$\begin{array}{ll}-288.264 & -.002\end{array}$

$(4,920.920)$

$2,332.080$

.018

$(4,161.799)$

reference category

$45,883.657 * * \quad .068$

$(14,893.652)$

$-24,312.682 * * \quad-.063$

$(8,882.010)$

$-13,193.008^{*}$

$(5,902.032)$

$-244.608$

.000

$(14,855.511)$

$65,981.973 * * \quad .070$

$(20,814.958)$

$.031++$

.093

$(.008)$

$23,930.770$

$(10,464.239)$

Table Continues 
$\mathrm{F}=26.805 \quad \mathrm{sig}=.0001$

${ }^{*} \mathrm{p}<.05 * * \mathrm{p}<.01+\mathrm{p}<.001 \quad++\mathrm{p}<.0001$ 
Table 30

OLS Regression Models of Miscellaneous Goods and Services Expenditure on Housing Provision Dummies and Controls (Bottom Decile of Household Income)

Independent Variables

$\underline{B} \quad$ Beta

$(\mathrm{SE})$

Homeowner without mortgage

reference category

Homeowner w/mortgage

315.653

.002

$(3,251.449)$

Family-owned

$-3,353.951$

$-.040$

$(2,064.119)$

Tenant

$-2,775.549$

$-.038$

$(1,853.703)$

Allotted

$4,226.746$

.005

$(18,912.633)$

Other

$$
-3,525.018
$$

$(2,049.637)$

Age of household head

33.804

.020

$(45.086)$

Number of persons

$-3,548.915$

$-.104$

$(3,282.310)$

Adult male living alone

$-15,238.042 * *$

$(5,641.333)$

Adult female living alone

$-12,740.417^{*}$

$(5,599.586)$

Table Continues 
Married couple/male head

Married couple/female head

Single parent/male head

Single parent/female head

Nuclear family/male head

Nuclear family/female head

Grandparents/grandchildren-

Male head

Grandparents/grandchildren-

Female head

Extended family/male head

Extended family/female head

Household income

Constant

$\mathrm{r}^{2}=.030$ $\begin{array}{ll}-7,590.746^{*} & -.166\end{array}$

$(3,173.797)$

$-8,711.605^{*} \quad-.116$

$(3,493.768)$

$-10,650.572 * \quad-.075$

$(4,520.179)$

$\begin{array}{ll}-7,599.518 * & -.072\end{array}$

$(3,822.877)$

reference category

$23,251.355$

.043

$(13,680.769)$

$-1,808.975 \quad-.006$

$(8,158.693)$

$-10,655.492 *$

$(5,421.393)$

$-1,951.537 \quad-.004$

$(13,645.734)$

$-5,291.193 \quad-.007$

$(19,119.866)$

$.020 * *$

.075

$(.007)$

$19,571.915$

$(9,612.070)$

Table Continues 


$$
\mathrm{F}=2.634 \quad \operatorname{sig}=.0001
$$

$* \mathrm{p}<.05 * * \mathrm{p}<.01+\mathrm{p}<.001++\mathrm{p}<.0001$ 